\title{
FLOOR RESPONSE OF YIELDING STRUCTURES
}

\author{
T. E. Kelly*
}

\section{ABSTRACT}

The New Zealand loading code, NZS 4203:1976, specifies design forces for parts and portions determined on the assumption that maximum floor accelerations are related to the yield level for ordinary structures. The code committee were aware that there was a scarcity of factual information on the subject and suggested that studies be carried out. The work described in this paper is aimed at investigating floor motions in buildings responding elastically and inelastically to earthquake motions and thus obtaining a basis for the design of parts and portions and also ancillary services.

Twelve structures ranging in height from one to eight storeys and of varying structural type were analysed using a dynamic computer program for elastic response and for two different levels of structure yield strength. Time histories of floor acceleration were obtained at each floor level and from these the maximum absolute values were obtained. To derive loadings on flexible and flexibly mounted components, response spectra were calculated for upper floors and thus the amplification factors relating floor spectra to ground spectra were derived.

The basic dynamic parameters used were the El Centro $1940 \mathrm{~N}-\mathrm{S}$ earthquake record, with constant damping and material strain hardening ratios. The effect of variations in these parameters was studied on a limited number of the structures.

From results obtained, tentative equations have been formulated for the design of both rigid and flexible components. For flexible components the floor amplification function was found to be very complex and due allowance must be made for uncertainties in dynamic parameters such as component damping and for factors such as higher mode effects influencing the response.

\section{INTRODUCTION}

In recent earthquakes a high proportion of damage to building structures has been in the failure of non-structural components $(1,2)$. The failure of items such as suspended ceilings, veneers, precast panels and mechanical and electrical services may endanger life both inside and outside buildings, restrict egress, and prevent speedy restoration of the normal functioning of the building. As more advanced techniques are applied toward a better understanding of structural systems, it is important that similar progress also be made towards a more accurate definition of the loads induced in non-structural components.

Loads may be induced in non-structural components either from deformations of the structural system or from motions introduced. at the points of fixing to the structure. Damage occurring from deformations imposed on the component may be reduced by separating the elements from the structure and codes, e.g. NZS 4203:1976(3), generally specify minimum separation distances. A general discussion on the separation of non-structural components is given in Reference 4.

For a component which is isolated from

* Senior Engineer, Office of the Chief

Structural Engineer, Head Office,

Ministry of Works and Development. deformations imposed by the structure, the earthquake loads are a function of the motion at the point of attachment. For stiff elements rigidly fixed to the structure, the force is directly proportional to the maximum acceleration of the point of attachment. If the component is flexible, or is flexibly mounted, the motion at the fixing point may itself be amplified by the dynamic response of the part. Design forces for the full range of non-structural components, therefore, require both the maximum acceleration and the frequency content of the floor motion.

Maximum floor acceleratons for elastic systems can be obtained by modal analysis techniques and a number of approximate methods for determining elastic floor response spectra have been proposed
$(5,6,7,8,9,10,11)$

These studies relate mainly to component design for structures such as offshore towers and nuclear power plants where design coefficients are such that the assumption of elastic behaviour is warranted. Liu et al (12) have produced design floor spectra for a range of elastic structures. Structures designed to building codes such as NZS 4203(3), ATC-3 (13) or SEAOC (14), however, remain elastic under only moderate earthquakes and the designer relies on inelastic deformations for energy dissipation in severe earthquakes. 
For such structures the only currently available analytical method of obtaining floor motions is time history analysis, which is too expensive to be used as part of normal design procedure for all but the most complex or important structures. Designers must look to codes for guidelines to forces to be used for the design of building components and this study is intended to provide data for the provision of such guidelines.

\section{REVIEW OF PREVIOUS STUDIES OF FLOOR MOTIONS}

Investigations of earthquake induced floor motions can be carried out by studying motions recorded in actual earthquakes, by experimental research using shaking tables and by various purely analytical techniques. Only a limited number of recorded floor motions are available, mainly from the san Fernando earthquake of 1971. A summary of floor motions recorded during that earthquake is given in References 12 and 21. Most instrumented buildings were high-rise structures with relatively long natural periods and sufficiently far removed from the epicentre to remain essentially elastic. In Reference 21 it was observed that "The overall character of the spectra from the buildings which behaved more or less linearly could not be differentiated from the spectra obtained from the non-linear buildings."

Much experimental work reported on the behaviour of components has been the result of Japanese investigations into the response of telecommunications systems. In References 22, 23 and 24 , the results of shaking table tests on particular items of equipment are reported.

Various theoretical studies have been carried out to determine approximate methods of deriving floor response spectra. Examples of these methods, which utilise modal analysis and/or Fourier analysis, are given in References 5 to 10 . Kost and Sharpe (15) provide a general overview of procedures used for equipment design and summarise the approach used in various U.S. codes. They comment on the methods used to derive floor motions and compare them on an example structure. Atalik(11) proposed a method for computing floor response spectra without time history analysis by using a ground motion filtered through a simple resonator.

Liu, Fagel and Dougherty (12) investigated floor motions recorded during the San Fernando earthquake and also carried out an analytical study of elastic, shear-type buildings with a range of soil, foundation and building parameters, using artificially generated earthquake time histories. Their statistical studies of the recorded floor motions gave a value of $0.7 \mathrm{~g}$ maximum acceleration for an $0.3 \mathrm{~g}$ peak ground acceleration to be used as a guide for expected in-building accelerations. The analytical studies produced a range of floor design spectra for various building parameters. They concluded that the floor accelerations were controlled by the frequency and damping characteristics of the building rather than by its height, and that it was erroneous to assume that equipment in short buildings requires less protection than in tall

\section{buildings.}

The analytical results in references quoted here all apply to linear elastic systems, hence correlation of the results obtained in the inelastic part of this study will not be possible.

\section{CODE REQUIREMENTS FOR THE DESIGN OF}

The provisions of the New Zealand code, NZS 4203:1976(3), for the derivation of loads on components are examined in some detail and those of two other codes, SEAOC (14) and ATC-3(13) more briefly. In each of these codes a multi-factor approach is used to derive the seismic force coefficient, based generally on seismic zoning, the position and performance of the part, and the consequences of its failure.

\subsection{New Zealand Code, NZS 4203:1976}

Design loadings on building components are specified in Clause 3.4.9, "Parts and portions of Buildings". Although the code committee recognises that "the real post-elastic situation is complex and floor motion studies should be made for special cases", it uses a basic assumption for design forces on components that "Maximum accelerations for a building are determined by its yield capacity for yielding structures or by the elastic damped response for nonyielding structures".

Elastic damped response maxima are taken as $0.6 \mathrm{~g}$ for single storey buildings and $1.33 \mathrm{~g}$ for multistorey buildings. Tabulated maximum values of $\mathrm{Cp}$, the design force coefficient, are based on these factors multiplied by a risk factor and reduced to take account of ductility of the component. The maximum values so obtained are then adjusted in accordance with the elevation of the part in the structure.

For yielding structures, an alternative value of $\mathrm{C}_{\mathrm{p}}$ may be calculated from the equation

$C_{p}=S_{P} M_{P} K_{P} R_{P} C_{d}$

where

$S_{p}=$ structural type factor for the part, varying from 1.0 for ductile parts to 3.0 for brittle parts.

$M_{p}=$ material factor for the part, ranging from 0.8 to 1.2

$\mathrm{R}_{\mathrm{p}}=$ risk factor, ranging from 1.0 to 2.0

$c_{d}=$ seismic base shear coefficient for the structure

$\mathrm{K}_{\mathrm{p}}=$ position factor, including a 1.5 factor for building overstrength. $\mathrm{K}_{\mathrm{p}}$ varies as shown in Figure $2(\mathrm{a})$.

The values of $C_{p}$ derived from this equation are not permitted to be less than tabulated minimum values and need not be greater than the factored elastic response values. This alternative derivation of $C_{p}$ basicaliy assumes an acceleration of 1.5 $\mathrm{C}_{d}$ at the centre of mass of the structure and then, because this level of acceleration 
was expected to be reached in moderate earthquakes, increasing it for brittle parts.

The code committee realised that, for a number of reasons, $1.5 \mathrm{C} d$ was not necessarily the maximum acceleration to be expected and some margin must be available against sudden failure where the consequences of such failure are serious. The more severe factors are intended to discourage the use of brittle parts, e.g. unreinforced masonry.

In practical situations, various values of $\mathrm{C}_{\mathrm{p}}, \mathrm{C}_{\mathrm{p}} \max$ and $\mathrm{C}_{\mathrm{p}}$ min may govern and although $\mathrm{C}_{\mathrm{p}}$ generaliy increase with height, the distribution may be complex. Specific clauses apply to particular elements such as lift machinery, connections and suspended cejlings.

\subsection{SEAOC COde}

The SEAOC code ${ }^{(14)}$ derives lateral forces on components from the equation

$\mathrm{F}_{\mathrm{p}}=\mathrm{ZIC}_{\mathrm{p}} \mathrm{SW}$

where

$Z$ = seismic zone coefficient $(1.0$ for highest seismicity)

I = importance factcr, varying from 1.0 to 1.5

$\mathrm{w}_{\mathrm{p}}=$ weight of component

$S$ = coefficient for soil-structure interaction, from 1.0 to 1.5

$C_{p}=$ tabulated force coefficient, ranging from 0.12 to 2.0

The values of $C_{p}$ are increased by $50 \%$ for slender structures and various limitations apply to maximum and minimum values of the products of some of the factors listed above. There is no provision for the force coefficient to vary with position of the part in the structure.

For flexible and flexibly mounted equipment the SEAOC code requires that "consideration he given to both the dynamic properties of the equipment and to the building or structure in which it is placed".

\section{3 ATC-3 Recommended Procedures}

In its final review draft, the Applied Technology Council(13) recommends that forces on architectural components be derived from

$F_{p}=C_{p} P W_{p} A_{2}$

where

$\mathrm{P}=$ performance criteria $(0.5$ to 1.5$)$

$W_{\mathrm{p}}=$ weight of component

$\hat{A}_{2}=$ seismic coefficient representing effective peak velocity, with a maximum value of 0.4

$C_{\rho}=$ tabulated seismic coefficient ranging from 0.60 to 3.0

Performance criteria are specified depending on the hazard exposure and type of component.
For mechanical and electrical components ATC-3 uses the relationship above, modified by two factors, Me and $\mathrm{Mx}$. Me is an amplification factor with a value of 1.0 for fixed components and 2.0 if the component period is between 0.60 and 1.40 times that of the supporting structure. $\mathrm{Mx}$ is an amplification factor relating variation of $\mathrm{Fp}$ with height, as shown in Figure 2(c).

An alternative procedure in ATC-3, suggested by the SEAOC ad hoc Committee, replaces the equation for $\mathrm{F}_{\mathrm{p}}$ above by

$F_{p}=A_{2} C_{p} W_{p} a_{e}$ for buildings of period less

and $\mathrm{F}_{\mathrm{p}}=2.0 \mathrm{~A}_{2} \mathrm{C}_{\mathrm{p}} \mathrm{W}_{\mathrm{p}} \mathrm{a}_{\mathrm{e}}$ for buildings of period

In these equations $a_{e}$ has the same values as Me above. Linear interpolation is used for structures of period between 0.2 and 1.0 secs. Tabulated values of $C_{p}$ have been altered and in the alternative procedure $C_{p}$ is a function of hazard exposure, thus replacing the product $\mathrm{PC}_{\mathrm{P}}$. This suggested procedure removes the dependence of $\mathrm{Fp}_{\mathrm{p}}$ on the location of the component in the structure.

\section{SCOPE OF THE PRESENT STUDY}

For this study low to medium rise structures of four main structural types were chosen as representative of the majority of buildings currently designed in New Zealand. The numbers of floors were taken as 1,2, 4 and 8 and the structural types considered were reinforced concrete ductile frames, low rise braced steel frames, medium height coupled shear walls and cantilever shear walls. The structures were analysed without consideration of the dynamic effects of the components, and therefore results derived apply only to components which fulfil the following two conditions:

(1) component separation is sufficient to prevent structural deformations from applying loads to the component, and

(2) the mass and stiffness properties of the component are such that their effect on the dynamic behaviour of the structure is negligible, at least in motions of the intensity considered here.

Guidelines issued by the Nuclear Regulatory Commission in respect of the second of these provisions are given in reference 15 as:

(1) If $R_{m}<0.01$, uncoupling can be assumed for any $R_{f}$.

(2) If $0.01<R_{m}<0.10$, uncoupling can be assumed if $0.8>R_{f}>1.25$.

(3) If $R_{m}>0.10$, an approximate model of the subsystem should be included in the primary system model.

where

$R_{m}$ is the ratio of the mass of the component to the mass of the structure, and $R_{f}$ is the ratio of the frequency of the 
component to the frequency of the structure.

\section{COMPUTATION OF FLOOR RESPONSE}

The twelve structures shown in Figure 1 were designed in accordance with the New Zealand Loadings Code(3) and the relevant materials codes $(17,18)$ and analysed using the DRAIN-2D(16) computer program. This program is restricfed to plane frames and solves the equations of motion using a step-by-step integration method to obtain relative accelerations, velocities and displacements.

The following general assumptions were made for each structure:

(1) Frames were spaced at $6.0 \mathrm{~m}$ centres, masonry walls at $15.0 \mathrm{~m}$ centres and reinforced concrete walls at $30.0 \mathrm{~m}$ centres. Fuil fioor diaphragm action was assumed.

(2) All floors, including the top, were assumed to be $150 \mathrm{~mm}$ in-situ concrete slabs with office-type live Ioads of $2.5 \mathrm{kPa}$.

(3) For calculating the seismic coefficient, $\mathrm{C}_{\mathrm{d}}$, the factors were derived as follows :

$C=$ value for zone $A$ on rigid subsoil

$I=R=1.0$

$S=$ as per Table 5, NZS 4203

$\mathrm{M}=" \| "$ " 6 "

(4) Interstorey height was constant at $3.6 \mathrm{~m}$ for all structures.

(5) Material strengths used were:

Concrete $f_{\mathrm{C}}^{\prime}=30 \mathrm{MPa}$

Structural Steel $\mathrm{F}_{\mathrm{Y}}=250 \mathrm{MPa}$

Reinforcing steel $\mathrm{f}_{\mathrm{y}}=275 \mathrm{MPa}$

Masonry $\mathrm{f}_{\mathrm{m}}^{\prime}=8 \mathrm{MPa}$

The structures were designed only to the extent necessary for the computer model, i.e. shear steel, confining steel etc., were not detailed. However, all structures were checked to ensure that selected dimensions were suitable for a complete design.

For the analyses the El Centro $1940 \mathrm{~N}-\mathrm{S}$ component was used as the input earthquake record with structural damping of $5 \%$ of critical. The yield function for all members was a bilinear non-degrading hysteretic curve with a $3 \%$ strain hardening ratio after yield. The effect of variations in each of these parameters was studied on a limited number of structures.

Three strength levels were specified for each of the structures, (1) a strength corresponding to the code specified base shear coefficient, $C_{d},(2)$ an increase of $50 \%$ over the code specified level to allow for factors causing overstrength such as design approximations, capacity reduction factors and actual material strengths, i.e. effectively a probable strength corresponding to $1.5 \mathrm{C}_{\mathrm{d}}$, and (3) with infinite strength, giving fully elastic response.

For each analysis time histories of absolute floor accelerations were obtained, maximum values were extracted and floor response spectra were computed. To obtain the floor spectra, 18 oscillator periods ranging from 0.05 to 4.00 seconds were used. No attempt was made to use oscillator periods exactly corresponding to computed structure periods as it was felt that exact coincidence would lead to a computed degree of resonance unlikely to be attained in any real situation where the period of the structure would vary to some extent.

\section{DYNAMIC RESPONSE OF STRUCTURES ANALYSED}

The dynamic response of the twelve structures used in this investigation is summarised in Table $\mathrm{l}$. and in Figures 3,4 and 5. Figures 3 to 5 show the distribution and extent of inelasticity in each of the yielding structures. All hinges shown, and the maximum plastic rotations listed, did not necessarily occur simultaneously.

The ductile frames behaved in accordance with the design philosophy adopted, most inelastic action being confined to the beam members. Of these frames, only the twostorey structure formed sufficient plastic hinges to create a mechanism. The 8-storey frame formed no column hinges and the 4storey frame only one base hinge. Maximum plastic rotations generally decreased with height although the 8 storey frame had maximum rotations at the third floor level, indicating a shear distribution differing from that assumed for the static analysis.

Essentially the cantilever shear wall structures form a mechanism once a wall base hinge occurs, and in the analyses this happened for all such structures. However, the use of elements yielding in flexure is not a good model for shear walls of comparatively large breadth to height ratios as inelasticity is mainly in the form of shear yielding. Therefore, although Figure 4 shows discrete plastic hinges at floor levels, actual inelastic behaviour would be in the form of diagonal shear cracking. As with the ductile frame, the plastic rotations in the 8 storey cantilever shear wall show the effects of higher modes.

The coupled shear walls both formed mechanisms, with hinges in all coupling beams and at wall bases. The wall elements also had hinging at floors above ground level but in all such cases the extent of wall hinging was small compared with that in the coupling beams. In the braced frames inelastic action was confined to tensile extension of the diagonal braces.

The displacements and maximum base shears listed in Table 1 demonstrate the effects of inelasticity on structural response. In some structures the elastic displacements were greater than those occurring in the yielding structure, whereas in others the inelastic displacements were the greater. This illustrates the difficulties in determining the response of yielding structures, which is a complex function of the type of motion, yield level of the structure relative to the peak effective ground acceleration and the period of the structure. In Figure 6 the elastic period of each structure is plotted on the response spectrum derived from the first 10 seconds of the El Centro $1940 \mathrm{~N}-\mathrm{S}$ 
component. Generally, structures which had increased displacements for elastic response lie on the falling portion of the spectrum. The New Zealand Loadings Code requires that the deflections calculated in an equivalent static analysis be increased by only a portion of the expected dynamic magnification and for the modified deflections to be less than 0.01 of the storey height $-36 \mathrm{~mm}$ for these structures. It is not surprising, therefore, to find that the braced frames with a strength level of $1.0 \mathrm{C}_{\mathrm{d}}$ and the two-storey elastic frame had deflections exceeding the permitted maximum.

For each analysis Table 1 lists the maximum base shears and expresses this as a fraction of the total weight of the structure. This proportion is generally higher than the design shear coefficient, resulting from the cumulative effect of two factors, one being overstrength arising from such effects as strain hardening and minimum steel requirements and the other being shear distributions differing from the assumed distribution of the equivalent static loads used for design. The largest discrepancies are found in the ductile frames and coupled shear walls where the overcapacity required in vertical members means that even after hinging in all horizontal members and at base level extra shear input can be accommodated by variations in shear distributions. These structures therefore have an "overstrength" over and above the 50\% allowance for material strength, capacity reduction factors, etc. These effects are discussed more fully in Reference 26 .

In the determination of the dynamic response of structures three of the most indeterminate parameters are the input earthquake record, the damping fraction and the strain hardening ratio. The effect of variations in these parameters over what was considered to be their extreme range was examined on two of the structures in this series.

The 8-storey ductile frame and the 4-storey cantilever wall were each subjected to six earthquakes in addition to the "basic" El Centro $1940 \mathrm{~N}-\mathrm{S}$ record. The records used were:

(a) $1.5 \times \mathrm{El}$ Centro $1940 \mathrm{~N}-\mathrm{S}$

(b) Artificial earthquake Al

(c) Artificial earthquake A2

(d) Artiricial earthquake BI

(e) Artificial earthquake B2

(f) The Pacoima Dam record of the San Fernando 1971 earthquake.

The artificial records are those generated by Jennings et al (19). The Type A series are intended to simulate earthquakes of magnitude about $150 \%$ that of EI Centro, 1940 and the $B$ series to be approximately equivalent to El Centro, 1940. Each record was analysed for 10 secs only and as the $A$ and $B$ series have durations of 120 secs and 50 secs respectively the peak response would not necessarily be encountered. The Pacoima Dam record has very high peak ground accelerations greater than $1.0 \mathrm{~g}$. The response of the two selected structures to this suite of earthquake records is summarised in Table $3(a)$. The range of displacements is very large, with factors of 5 and 2.7 in the top floor displacements between the $E I$ Centro and Pacoima Dam analyses f.... the 4-storey and 8-storey structures respectively. As these are yielding structures the range of base shears for the various earthquakes is considerably less.

In the main study the damping ratio for all structures was set at 5\% of critical. To study the effect of variations in this value, the 2 -storey braced frame and 8-storey ductile frame were analysed for damping ratios of $2 \%$ and 10\%. 2\% would represent a lower bound of damping in a steel structure and $10 \%$ an upper bound for a concrete structure. The results of these analyses are summarised in Table 4(a). As expected, higher damping reduced the response of both structures, although to a lesser extent in the long period ductile frame. Response spectra plots generally show a decreasing relative effect of damping as the period increases.

The effects of assuming strain hardening of $0 \%$ (perfectly plastic), $1 \frac{1}{2} \%$ and $3 \%$ on a 2-storey and an 8-storey structure are summarised in Table $5(a)$. The strain hardening has a smaller effect than the damping factor and differences are comparatively minor even in the braced frame which proved sensitive to changes in other dynamic parameters. It would be presumed that the effect would also be small on the other structures.

These parametric studies indicate that the most important parameter is the input ground motion used, and it is known that even apparently similar earthquake records can produce markedly different responses in inelastic structures $(25)$. The results of experimental studies enable damping and strain hardening ratios to be predicted to an accuracy within the ranges used above but on even the most intensely studied sites no techniques are yet available to accurately predict the form of the earthquake motion. Therefore in a study such as this due allowance must be made for a wide variation in the input record.

\section{RESPONSE OF RIGID COMPONENTS}

The maximum absolute accelerations which define the loadings on rigid components are derived from the equation of motion

$$
[M]\{\ddot{y}\}+[C]\{\dot{x}\}+[K]\{x\}=0
$$

where

$\{\ddot{y}\}$ is the vector of absolute acceleration

$\{\mathrm{x}\}$ is the vector of motion relative to the base

and

$[\mathrm{M}],[\mathrm{C}]$ and $[\mathrm{K}]$ are the mass, damping and stiffness matrices for the structure respectively.

For a yielding structure $[\mathrm{K}]\{\mathrm{x}\}$ will be restricted to the maximum base shear, $\mathrm{V}_{\mathrm{u}}$, which is the design yield strength plus any strain hardening. If the effect of damping is assumed relatively small,

$[\mathrm{M}]\{\ddot{y}\}_{\max } \doteqdot \mathrm{V}_{\mathrm{u}^{\prime}}$ 
or, for uniformly distributed mass,

$\frac{M}{n}\left(\dot{y}_{1}+\ddot{y}_{2}+\ldots \ddot{y}_{n_{\max }}\right) \doteq v_{u}$

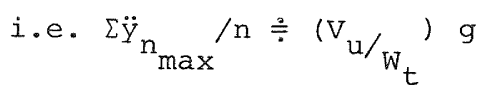

It therefore follows that

$\Sigma \ddot{y}_{n} / n<\left(v u_{t} / w_{t}\right) g$,

i.e.

I. The average acceleration over all floors at any particular timestop should not exceed the maximum base shear coefficient.

Because $\{\ddot{y}\}$ varies as the earthquake excites various combinations of the structures normal modes, this relationship serves as a check on the accuracy of results rather than as an explicit means of obtaining floor accelerations.

The maximum acceleration at any point can be considered as

$\ddot{y}=\ddot{x}+\ddot{z}$

where

$\ddot{\mathrm{x}}=$ acceleration relative to the base

$\ddot{z}=$ absolute acceleration of the base

The structural floor acceleration will differ increasingly from the ground acceleration with increase of storey number. It follows that:

II. For response largely in the first mode, $\ddot{x}$ wizl be small at lower levels and the maximum accelerations should be similar to that of the ground motion.

III. For higher floors, the relative acceleration $\ddot{x}$ wizl be the dominant component of the absolute floor acceleration, and ground accelerations will have a lesser effect.

Figure 6 illustrates the extent to which the three factors discussed above are reflected in the maximum floor accelerations derived from the dynamic analyses.

Figure 7 and 8 illustrate the effect of yielding on maximum floor accelerations. For the yielding structure there is less definite periodicity and the maximum values are considerably less than for the elastic structure. The accelerations in the 4-storey cantilever wall, plotted in Figure 9, show a large second mode contribution except at the third floor level, which is close to the stationary node for second mode response.

The maximum floor accelerations for each structure and yield level are plotted in Figure 10, and although the distributions with height are irregular, some trends are discernible:

(1) accelerations increase with height;

(2) The rate of change of acceleration with height decreases as the yield level decreases and increases as the total height of the structure decreases; which had $H / D>3$, show a definite increase in the rate of change of acceleration at topmost floors.

The effect of varying the earthquake record is shown on Figure 11 for two of the structures in the series. The artificial records are those generated by Jennings et al(19). In spite of considerable differences in earthquake record the least squares "best-fit" relationship indicates a slope which varies very little and a constant term which is approximately equal to the maximum ground acceleration.

Increased structural damping reduced both absolute values and the rate of change with height of floor accelerations. The maximum decreases were $43 \%$ and $17 \%$ for the 2-storey braced frame and 8-storey ductile frame respectively for an increase in damping from $2 \%$ to 10\%. Strain hardening proved to have less effect than either the damping ratio or the earthquake record, with floor accelerations generally slightly higher for increased strain hardening.

For earthquakes of moderate intensity, straining the structures to the level of their elastic limit, accelerations were disproportionately greater than in the yielding structures. Maximum floor accelerations in the structures responding elastically to $1 / 3 \mathrm{El}$ Centro reached values of $2 / 3$ the accelerations in yielding structures, portending high component loadings in even moderate earthquake intensities.

\section{RESPONSE OF FLEXIBLE AND FLEXIBLY MOUNTED COMPONENTS}

It is assumed in this study that components can be modelled as elastic single-degree-of-freedom systems, for which the equation of motion can be expressed as

$\ddot{x}_{p}(t)+2 \omega \lambda \dot{x}_{p}(t)+\omega^{2} x_{p}(t)=-\ddot{y}_{a}(t)$

where $\mathrm{x}$ is the relative motion of the component relative to its point of attachment and $y$ the absolute motion of the point of attachment. $\omega$ and $\lambda$ are respectively the natural frequency and damping of the component.

For components mounted on upper floors the input motion, $\ddot{y}_{a}(t)$, is a function of both the ground motion and the structure's dynamic properties. If this filtered motion has a frequency close to that of the component resonance will occur and the response of the component will be amplified. To determine the extent of this resonance floor response spectra are plotted for a range of component periods. To isolate the effect of the structure itself on the floor response spectra an amplification factor, A, can be derived. This factor is defined here as the ratio of the response of a singledegree-of-freedom oscillator at the particular floor level to the response of an oscillator of similar period at ground level.

\subsection{Floor Response from Dynamic Analyses}

Floor response spectra and amplification 
factors for all structures are reproduced in Reference 20, and those derived for the 8storey coupled shear wall are presented in Figures 12 and 13 to illustrate general features:

(1) Maximum pseudo-spectral accelerations and velocities, PSA and PSV, occur when the period of the component, $\mathrm{T}_{\mathrm{p}}$, coincides with the natural period of the structure, $\mathrm{T}_{1}$. The maximum values increase progressively with height, reflecting the fundamental mode shape.

(2) At $T_{2}$ a second peak of PSA and A occurs. As PSV $=\frac{T}{2 \pi}$ PSA the velocity is smaller relative $\overline{2 \pi}$ to acceleration for shorter periods and hence the peak is PSV is less marked. This second peak reflects the second mode shape, with maximum values at the second and eighth floors and a minimum value at the sixth floor which is close to the zero node point for the second mode.

(3) For small $T_{p}$, PSA tends towards the maximum floor acceleration and so $A$ increases with height.

(4) The peak values of PSA, PSV and A at $\mathrm{T}_{1}$ reduce considerably when yielding occurs in the structure due to stiffness changes varying $\mathrm{T}_{1}$. For higher mode response displacements are generally smaller and do not cause yielding to the same extent so that peaks occurring at $\mathrm{T}_{2}$ are little different between yielding and elastic response.

(5) When $\mathrm{T}_{\mathrm{p}}$ is greater than $\mathrm{T}_{1}$ the floor response spectra ordinates gradually converge to the ground spectra values and thus $A$ tends towards unity.

\subsection{Effect of Dynamic Parameters on Floor Response}

For varying earthquake records the shape of the floor response spectra varies considerably but as shown in Figure 14 the form of the amplification factor remains essentially the same. Thus the filtering effect of the structure is largely independent of earthquake record, although there is a broadening and some increase in peak values at resonance.

Decreased structural damping generally increased floor response over the full frequency range. The 2-storey braced frame was more sensitive than the 8-storey ductile frame, with an increase in A from 2.4 to 4.6 in the former and from 3.1 to 4.0 in the latter for a decrease in damping from $10 \%$ to $2 \%$. The strain hardening ratio had little effect on the floor response spectra.

Component damping of $5 \%$ was generally used, and a decrease to $1 \%$ increased PSA, and thus $A$, by a factor of 2 or more. For mechanical and electrical equipment elastic damping would range from 1\% to $4 \%$, the lower values applying for small amplitudes. As some degree of hysteretic damping would occur at the levels of load indicated in this study, 5\% is probably a reasonabie value of component damping for severe earthquakes, with lower values applying for moderate earthquakes.

9. PROPOSED DESIGN COEFFICIENTS FOR NONSTRUCTURAL COMPONENTS

Parameters included in this study relate to the dynamic characteristics of the structure and component and to the input ground motion. Other parameters such as seismic zoning, importance of the component, ductility of the component and the consequences of its failure are outside the scope of this report. The formulation proposed in this section gives design coefficients based on probable accelerations derived in this study, and allowances would need to be made for the factors mentioned above.

From the results obtained in these analyses a design equation would have the form

$c_{p}=c K_{e l} K_{e 2}$

where

$C_{p} \quad=$ design coefficient for a component on an upper floor

C = design coefficient for a component of similar period on the ground

$\mathrm{K}_{\mathrm{pl}} \quad=$ height amplification factor

$=1+\frac{\mathrm{C}_{\mathrm{d}} \mathrm{K}}{\left|\ddot{\vec{a}}_{\mathrm{g}}\right| \max }$ for $\mathrm{T}_{\mathrm{p}} / \mathrm{T}_{1}<3$

$=1.0 \quad$ for $\mathrm{T}_{\mathrm{p}} / \mathrm{T}_{1}>3$

$\mathrm{K}_{\mathrm{p} 2} \quad=$ resonance factor

$=\left(1+\frac{N}{\mathrm{H}}\right)$ for $0.6<\mathrm{T}_{\mathrm{p}} / \mathrm{T}_{1}<2.0$

$=1.0$ otherwise

$\mathrm{c}_{\mathrm{d}} \quad=$ base shear coefficient, including overstrength

$\mathrm{N}=$ floor number

$\mathrm{H}=$ total number of floors

$\left|\ddot{a}_{g}\right|_{\max }=$ maximum ground acceleration

and $\mathrm{K}_{\mathrm{X}}$ is $\mathrm{a}^{\mathrm{a}}$ height factor as defined in NZS $4203(3)$. $\mathrm{K}_{\mathrm{x}}$ generally is equivalent to the height of the floor divided by the height to the centre of gravity of the structure, and therefore has a linear distribution from zero at ground level through unity at the structure's centre of gravity. The formulation for $\mathrm{K}_{\mathrm{x}}$ given in NZS 4203 is such that for slender structures $(H / D>3) K_{X}$ is increased at roof level.

This proposed equation is empirical and reflects the following features of the calculated floor motions:

(1) For $\mathrm{T}_{\mathrm{p}} / \mathrm{T}_{1}$ small the maximum accelerations increase linearly with height such that

$|\ddot{a}|_{\max }=\left|\ddot{a}_{g}\right|_{\max }+c_{d} K_{x}$ which is divided by $\left|\ddot{a}_{g}\right|_{\max }$ to give the height
amplification factor.

(2) For $T_{p} / T_{1}$ large, the floor spectral accelerations are approximately equal to the ordinates of the ground spectrum.

(3) For $\mathrm{T}_{\mathrm{p}} / \mathrm{T}_{1}$ close to unity an additional amplification occurs, with a value of approximately 2.0 at top floor level for yielding structures.

In Reference 20 this formulation is 
shown to give a reasonable approximation to values computed from the dynamic analyses except when higher mode effects are important. The range of structures studied proved insufficient to define parameters which may indicate higher mode influences.

For the specific procedures of the New Zealand code, NZS $4203^{(3)}$, the general equation given above may be replaced by

$c_{p}=s_{p}^{M} R_{p} K_{e 1} K_{e 2}$

where $S_{p}, M_{p}$ and $R_{p}$ are as defined in
NZS 4203

$$
\begin{aligned}
K_{e l} & =\left(C I+0.5 C_{d} K_{x}\right) & & \text { for } T_{p} / T_{I}<3 \\
& =C I & & \text { for } T_{p} / T_{I}>3 \\
K_{e 2} & =\left(1+\frac{N}{H}\right) & & \text { for } 0.6<T_{p} / T_{I}<2.0 \\
& =1.0 & & \text { otherwise }
\end{aligned}
$$

This provides a level of protection under $\mathrm{El}$ Centro intensity motions for brittle parts in Zone $B$ structures equivalent to that of the previous formulation when $I=M_{p}=$ $\mathrm{R}_{\mathrm{p}}=1.0$.

Upper bound spectra from all structures are plotted in Figure $15(\mathrm{a})$ and a smoothed spectrum for a strength level of $1.5 \mathrm{C}$ is plotted in Figure 15(b). These may be used in the design of "off-the-shelf" components which may be installed in a variety of structures. On Figure $15(b)$ the spectrum derived by Liu et al(12) is also plotted, and it is seen that even though their study was restricted to elastic structures, the inelastic structures studied here give higher accelerations for $T_{p}$ less than 0.8 secs. The accelerations in this period range generally occurred in the braced frames and shear walls, structural types not included in the study by Liu et al.

\section{CONCLUSIONS}

The floor accelerations obtained from the study of twelve yielding structures provide basic data for the provision of code guidelines for design of components mounted in multistorey structures. A design equation is proposed, which would need to be tempered by engineering judgement to allow for uncertainties in dynamic properties but which, nevertheless, does provide necessary practical guidelines, since realistic floor motion studies are not likely to become a feature of everyday design practice for some time, if ever. A number of general features of floor accelerations in the structures studied were:

(1) For yielding structures higher mode effects are such that floor accelerations reach values several times as high as the design base shear coefficient.

(2) The influence of the maximum ground acceleration is paramount in lower floor accelerations while upper floor accelerations are influenced by the dynamic characteristics and yield level of the structure.

(3) Accelerations increase with height, the rate of change increasing with increasing yield strength and decreasing with total height of structure.
(4) For yielding structures the rate of change of acceleration with height is generally independent of the ground motion. (5) Under moderate earthquakes of intensity I/3 El Centro the floor accelerations may reach $2 / 3$ of more the values occurring in yielding structures under the full EI Centro ground motion.

(6) For flexible components maximum accelerations and velocities occur when the fundamental periods of the structure and component coincide, but secondary acceleration peaks at higher structural modes may be of the same order of magnitude.

(7) Acceleration peaks reflect the mode shape, increasing progressively with height for the first mode, whereas for second mode peaks highest accelerations occur at lowest and highest floors.

(8) Inelastic response considerably reduces amplification at the coincidence of $\mathrm{T} I$ and $T_{p}$ compared with elastic response but has little effect at higher modes.

(9) The filtering effect of the structure is largely independent of the earthquake record, allowing a design procedure based on an amplification function to be applied to any given ground spectrum.

(10) The most important variable for flexible components is the degree of component damping. Amplification may increase by a factor of 2 or more for a decrease in component damping from 5\% to $1 \%$.

\section{ACKNOWLEDGEMENTS}

The studies reported in this paper were carried out as part of a continuing study of seismic aspects of building design being conducted in the structural section of the Ministry of Works and Development under the general direction of Mr. B. W. Buchanan. Mr. O. A. Glogau, Chief Structural Engineer, initiated this study and the writer wishes to thank both him and Mr. Buchanan for their advice and assistance. Thanks are also due to Dr. R. I. Skinner of the Department of Scientific and Industrial Research for his helpful comments.

\section{REFERENCES}

1. San Fernando, California, Earthquake of February 9, 1971, U.S. Department of Commerce, 1973. Murphy, L. M., Editor.

2. Fintel, M., Quake Lesson from Managua : Revise Concrete Building Design?, Civil Engineering - ASCE, August 1973.

3. Code of Practice for General Structural Design and Design Loadings for Buildings, NZS 4203:1976, Standards Association of New Zealand.

4. Glogau, O. A., Separation of Non-Structural Components in Buildings, Bulletin of the N.Z. National Society for Earthquake Engineering, Vol. 9, No. 3, September, 1976.

5. Penzien, J. and Chopra, A. K. , Earthquake Response of Appendage on a Multi-Storey Building, Proc. 3rd World Conference for Earthquake Engineering, New Zealand, 1965.

6. Skinner, R. I., Skilton, D.W.C. and Laws, D. A., Unbalanced Buildings and Buildings with Light Towers, Under Earthquake Forces, Proc. 3rd World Conference for Earthquake Engineering, New Zealand, 1965.

7. Seismic Design of Nuclear Power Plants, MIT Press, 1970. Hansen, R. J., Editor. 
8. Kapur, K. K. and Shao, L. C., Generation of Seismic Floor Response Spectra for Equipment Design, Proc. Conference on Structural Design of Nuclear Plant Facilities, ASCE, Chicago, 1973.

9. Scanlan, R. H. and Sachs, K., Earthquake Time Histories and Response Spectra, ASCE Vol. 100, EM4, Proc. Paper 10703, August 1974.

10. Singh, M. P., Generation of Seismic Floor Spectra, ASCE Vol. 101, EM5, October 1975.

11. Atalik, T. S., An Alternative Definition of Instructive Response Spectra, Earthquake Engineering and Structural Dynamics, Journal of International Association for Earthquake Engineering, Vol. 6, No. 1, 1978 .

12. Liu, S. C., Fagel, L. W. E. and Dougherty, M. R., Earthquake Induced In-Building Motion Criteria, ASCE, Vol. 103, STI, January 1977.

13. Final Review Draft of Recommended Comprehensive Seismic Design Provisions for Buildings, Applied Technology Council, Palo Alto, California, 1977.

14. Recommended Lateral Force Requirements, Structural Engineers Association of California, 1974 .

15. Kost, G. and Sharpe, R. L., Seismic Resistant Design of Piping, Equipment and Appurtenances for Offshore Structures, 9th Annual Offshore Technology Conference, Houston, Texas, 1977.

16. Powell, G. H., DRAIN-D User's Guide, Earthquake Engineering Research Centre, Report EERC 73-22, University of California, 1973 .

17. Code tor Design of Steel Structures, NZS 3404:1977, Standards Association of New Zealand.

18. Draft New Zealand Standard : The Design of Concrete Structures, DZ3101:1978, Standards Association of New Zealand.

19. Jennings, P. C., Housner, G. W. and Tsai, N. C., Simulated Earthquake Motions for Design Purposes, Proc. 4th World Conference on Earthquake Engineering, Chile, 1969.

20. Kelly, T. E., Floor Response of Yielding Structures, Research and Development Report 78/1, Ministry of Works and Development, Wellington, New Zealand, September 1978.

21. Simonson, G. M. and T. R., Basis for Seismic Resistant Design of Mechanical and Electrical Service Systems, Report funded by National Science Foundation/ Research Applied to National Needs, May 1976.

22. Kimura, E., "Earthquake Proof Design of Exchange Equipment, Japan Telecommunications Review, 1968.

23. Kimura, E. and Machizuki, I., Effects of Earthquakes on Telecommunications Facilities, Japan Telecommunications Review, 1969.

24. Sugimoti, Y., Konno, T., Hirama, S. and Niinou, K., Seismic Resistant Capacity of Information Processing Equipment, Review of the Electrical Communications Laboratories, Vol. 21, 1973.

25. Powell, G. H. and Row, D. G., Influence of Design and Analysis Assumptions on Computed Inelastic Response of Moderately Tall Frames, Earthquake Engineering Research Centre Report EERC 76-11, University of California, 1976.

26. Kelly, T. E., Uniaxial Dynamic Analysis of a Six-Storey Reinforced Concrete Framed Structure, Bulletin of the N.Z. National Society for Earthquake Engineering, Vol. 10, No. 1, 1977.

Paper received 2 November, 1978.

\begin{tabular}{|c|c|c|c|c|c|c|c|}
\hline & Structure & Yield & $\begin{array}{l}\text { Max. Top } \\
\text { Displace- } \\
\text { ment } \\
(\mathrm{mm})\end{array}$ & \begin{tabular}{c|} 
Max. Inter- \\
storey dis- \\
placement \\
$(\mathrm{mm})$
\end{tabular} & $\begin{array}{l}\text { Max. Base } \\
\text { Shear } \\
V_{u},(K N)\end{array}$ & \begin{tabular}{l|l}
$v_{u}$ \\
$v_{t}$ \\
\end{tabular} & $\begin{array}{l}\text { Design } \\
\text { Coeffic- } \\
\text { ient } \\
v_{\text {des }} / \omega_{t}\end{array}$ \\
\hline \multirow{4}{*}{ 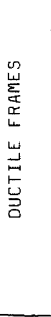 } & $\mathrm{FB}$ & \begin{tabular}{|l}
$1.0 C_{d}$ \\
$1.5 C_{d}$ \\
Elastic
\end{tabular} & $\begin{array}{l}107 \\
105 \\
165\end{array}$ & $\begin{array}{l}20 \\
22 \\
29\end{array}$ & $\begin{array}{r}790 \\
1056 \\
2366\end{array}$ & $\begin{array}{l}0.13 \\
0.17 \\
0.39\end{array}$ & $\begin{array}{l}0.076 \\
0.114\end{array}$ \\
\hline & $\mathrm{F} 4$ & \begin{tabular}{|l|}
$1.0 C_{d}$ \\
$1.5 C_{d}$ \\
Elastic
\end{tabular} & $\begin{array}{r}59 \\
65 \\
102\end{array}$ & $\begin{array}{l}22 \\
24 \\
34\end{array}$ & $\begin{array}{r}449 \\
613 \\
1430\end{array}$ & $\begin{array}{l}0.17 \\
0.24 \\
0.55\end{array}$ & $\begin{array}{l}0.100 \\
0.150\end{array}$ \\
\hline & $F 2$ & $\begin{array}{r}1.0 C \\
1.5 C_{d}^{d} \\
\text { Elastic } \\
\end{array}$ & $\begin{array}{l}55 \\
66 \\
84 \\
\end{array}$ & $\begin{array}{l}32 \\
33 \\
43 \\
\end{array}$ & $\begin{array}{l}187 \\
237 \\
538 \\
\end{array}$ & $\begin{array}{l}0.30 \\
0.38 \\
0.86 \\
\end{array}$ & $\begin{array}{l}0.15 \\
0.225\end{array}$ \\
\hline & F1 & $\begin{array}{c}1.0 C_{d}^{d} \\
1.5 C_{d}^{d} \\
\text { Elastic }\end{array}$ & $\begin{array}{l}13 \\
13 \\
13 \\
\end{array}$ & $\begin{array}{l}13 \\
13 \\
13\end{array}$ & $\begin{array}{l}60 \\
60 \\
60\end{array}$ & $\begin{array}{l}0.39 \\
0.39 \\
0.39\end{array}$ & $\begin{array}{l}0.15 \\
0.225\end{array}$ \\
\hline \multirow{4}{*}{ 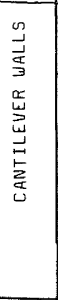 } & WE & $\begin{array}{r}1.0 C_{d} \\
1.5 C_{d} \\
\text { Elastid } \\
\end{array}$ & $\begin{array}{l}109 \\
104 \\
126 \\
\end{array}$ & $\begin{array}{l}20 \\
22 \\
22 \\
\end{array}$ & $\begin{array}{l}2561 \\
3569 \\
5716 \\
\end{array}$ & $\begin{array}{l}0.20 \\
0.28 \\
0.45\end{array}$ & $\begin{array}{l}0.12 \\
0.18\end{array}$ \\
\hline & 14 & $\begin{array}{c}1.0 C^{d} \\
1.5 C_{d} \\
\text { Elastic }\end{array}$ & $\begin{array}{l}43 \\
31 \\
32 \\
\end{array}$ & $\begin{array}{r}12 \\
9 \\
10 \\
\end{array}$ & $\begin{array}{l}1725 \\
2007 \\
3301\end{array}$ & $\begin{array}{l}0.29 \\
0.33 \\
0.55\end{array}$ & $\begin{array}{l}0.15 \\
0.225\end{array}$ \\
\hline & W2 & $\begin{array}{l}1.0 C_{d}^{d} \\
1.5 C_{d}^{d} \\
\text { Elastic }\end{array}$ & $\begin{array}{c}12 \\
10 \\
8\end{array}$ & $\begin{array}{l}6 \\
6 \\
5\end{array}$ & $\begin{array}{l}519 \\
668 \\
878\end{array}$ & $\begin{array}{l}0.36 \\
0.46 \\
0.63\end{array}$ & $\begin{array}{l}0.29 \\
0.435\end{array}$ \\
\hline & W1 & $\begin{array}{c}1.0 C_{d} \\
1.5 C_{d}^{d} \\
\text { Elastic }\end{array}$ & $\begin{array}{l}1 \\
1 \\
1\end{array}$ & $\begin{array}{l}1 \\
1 \\
1\end{array}$ & $\begin{array}{l}120 \\
131 \\
131\end{array}$ & $\begin{array}{l}0.31 \\
0.34 \\
0.34\end{array}$ & $\begin{array}{l}0.29 \\
0.435 \\
0.435\end{array}$ \\
\hline \multirow{2}{*}{ 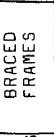 } & $\overline{82}$ & $\begin{array}{c}1.0 C_{d} \\
1.5 C_{d}^{d} \\
\text { Elastic }\end{array}$ & $\begin{array}{l}75 \\
30 \\
61\end{array}$ & $\begin{array}{l}38 \\
16 \\
30\end{array}$ & $\begin{array}{l}243 \\
326 \\
408\end{array}$ & \begin{tabular}{l|}
0.39 \\
0.52 \\
0.65
\end{tabular} & $\begin{array}{l}0.30 \\
0.45\end{array}$ \\
\hline & 81 & $\begin{array}{rl}1.0 C_{d}^{d} & 1.5 C_{d}^{d} \\
\text { Elastic } \\
\end{array}$ & $\begin{array}{l}43 \\
23 \\
19 \\
\end{array}$ & $\begin{array}{l}43 \\
23 \\
19 \\
\end{array}$ & $\begin{array}{l}48 \\
62 \\
73 \\
\end{array}$ & $\begin{array}{l}0.43 \\
0.56 \\
0.65 \\
\end{array}$ & $\begin{array}{l}0.24 \\
0.36\end{array}$ \\
\hline \multirow{2}{*}{ 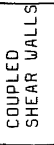 } & $\overline{C \theta}$ & $\begin{array}{c}1.0 C_{d} \\
1.5 C_{d} \\
\text { Elastic }\end{array}$ & $\begin{array}{r}73 \\
79 \\
108\end{array}$ & $\begin{array}{l}14 \\
14 \\
19\end{array}$ & $\begin{array}{l}2745 \\
3710 \\
6579\end{array}$ & $\begin{array}{l}0.22 \\
0.30 \\
0.54\end{array}$ & $\begin{array}{l}0.10 \\
0.15\end{array}$ \\
\hline & C4 & $\begin{array}{c}1.0 C \mathrm{~d} \\
1.5 C_{d}^{d} \\
\text { Elastic }\end{array}$ & $\begin{array}{l}60 \\
58 \\
69\end{array}$ & $\begin{array}{l}23 \\
21 \\
21\end{array}$ & $\begin{array}{l}1610 \\
2090 \\
4216\end{array}$ & $\begin{array}{l}0.27 \\
0.36 \\
0.72\end{array}$ & $\begin{array}{l}0.11 \\
0.165\end{array}$ \\
\hline
\end{tabular}




\begin{tabular}{|c|c|c|c|c|c|c|c|c|c|}
\hline & \multicolumn{3}{|c|}{ DUCTILE FRAMES } & \multirow{2}{*}{\multicolumn{3}{|c|}{$\begin{array}{l}\text { BRACED FRAMES } 1 \& 2 \\
\text { COUPLED WALLS } 4 \& 88 \\
\text { Yield strength }\end{array}$}} & \multicolumn{3}{|c|}{$\begin{array}{l}\text { CANTILEVER } \\
\text { WALLS }\end{array}$} \\
\hline & \multicolumn{3}{|c|}{ Yield strength } & & & & & ild sti & ength \\
\hline & $1.0 c_{d}$ & $1.5 C_{d}$ & Elas. & $1.0 C_{d}$ & $1.5 C_{d}$ & Elas. & $1.0 C_{d}$ & $1.5 C_{d}$ & Elas. \\
\hline $\begin{array}{c}1 \text { Storey } \\
\text { Floor } 1\end{array}$ & 0.41 & 0.42 & - & 0.50 & 0.64 & 0.73 & 0.47 & 0.48 & - \\
\hline $\begin{array}{l}2 \text { Storey } \\
\text { Floor } 1 \\
\text { " } 2\end{array}$ & $\begin{array}{l}0.42 \\
0.47\end{array}$ & $\begin{array}{l}0.42 \\
0.54\end{array}$ & $\begin{array}{l}0.69 \\
1.13\end{array}$ & $\begin{array}{l}1.06 \\
0.88\end{array}$ & $\begin{array}{l}0.75 \\
0.93\end{array}$ & $\begin{array}{l}0.84 \\
1.32\end{array}$ & $\begin{array}{l}0.45 \\
0.57\end{array}$ & $\begin{array}{l}0.50 \\
0.72\end{array}$ & $\begin{array}{l}0.49 \\
0.89\end{array}$ \\
\hline 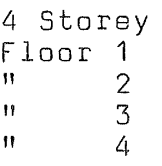 & $\begin{array}{l}0.31 \\
0.31 \\
0.39 \\
0.38\end{array}$ & $\begin{array}{l}0.31 \\
0.34 \\
0.47 \\
0.48\end{array}$ & $\begin{array}{l}0.44 \\
0.62 \\
0.70 \\
0.91\end{array}$ & $\begin{array}{l}0.39 \\
0.42 \\
0.38 \\
0.65\end{array}$ & $\begin{array}{l}0.39 \\
0.45 \\
0.48 \\
0.72\end{array}$ & $\begin{array}{l}0.45 \\
0.66 \\
0.83 \\
1.14\end{array}$ & $\begin{array}{l}0.54 \\
0.49 \\
0.40 \\
0.65\end{array}$ & $\begin{array}{l}0.46 \\
0.51 \\
0.51 \\
0.64\end{array}$ & $\begin{array}{l}0.39 \\
0.57 \\
0.68 \\
0.90\end{array}$ \\
\hline $\begin{array}{ll}8 & \text { Storey } \\
\text { Floor } & 1 \\
" ~ & 2 \\
" 1 & 3 \\
" & 4 \\
" 1 & 5 \\
" & 6 \\
" 1 & 7 \\
" & 8\end{array}$ & $\begin{array}{l}0.32 \\
0.27 \\
0.28 \\
0.27 \\
0.26 \\
0.26 \\
0.30 \\
0.35\end{array}$ & $\begin{array}{l}0.28 \\
0.31 \\
0.30 \\
0.35 \\
0.34 \\
0.31 \\
0.34 \\
0.39\end{array}$ & $\begin{array}{l}0.28 \\
0.37 \\
0.44 \\
0.53 \\
0.56 \\
0.60 \\
0.65 \\
0.73\end{array}$ & $\begin{array}{l}0.50 \\
0.41 \\
0.39 \\
0.37 \\
0.36 \\
0.37 \\
0.44 \\
0.64\end{array}$ & $\begin{array}{l}0.36 \\
0.44 \\
0.45 \\
0.51 \\
0.51 \\
0.50 \\
0.46 \\
0.64\end{array}$ & $\begin{array}{l}0.37 \\
0.46 \\
0.54 \\
0.56 \\
0.61 \\
0.34 \\
0.87 \\
1.16\end{array}$ & $\begin{array}{l}0.38 \\
0.41 \\
0.38 \\
0.46 \\
0.42 \\
0.44 \\
0.29 \\
0.54\end{array}$ & $\begin{array}{l}0.37 \\
0.37 \\
0.43 \\
0.60 \\
0.53 \\
0.56 \\
0.44 \\
0.70\end{array}$ & $\begin{array}{l}0.31 \\
0.41 \\
0.55 \\
0.62 \\
0.61 \\
0.56 \\
0.73 \\
1.05\end{array}$ \\
\hline
\end{tabular}

NOTES:

(1) All accelerations are multiples of gravity, 9.

(2) Where elastic values are not given, the structure responded elastically with a yield level of $1.5 \times C_{d}$

(3) Accelerations are absolute maxima, i.e. $\left|a^{\circ}\right| \max$ and are not necessarily of the same sign nor occurring simultaneously.

(4) Floor 1 is the first suspended floor.

TABLE 2: MAXIMUM ABSOLUTE FLOOR ACCELERATIONS

\begin{tabular}{|c|c|c|c|c|c|c|c|}
\hline & $\begin{array}{l}\text { Earthquake } \\
\text { Record }\end{array}$ & $\begin{array}{l}\text { Yield } \\
\text { Level }\end{array}$ & $\begin{array}{c}\Delta T_{(\mathrm{mm})} \\
\Delta \circ p\end{array}$ & $\begin{aligned} \Delta \Delta_{i} \max \\
(\mathrm{mm})\end{aligned}$ & $\begin{array}{l}v_{u} \\
(k N)\end{array}$ & $\frac{v_{u}}{w_{t}}$ & $\begin{array}{l}\text { Design } \\
\text { Coeff. }\end{array}$ \\
\hline 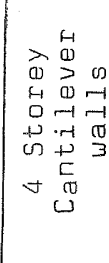 & 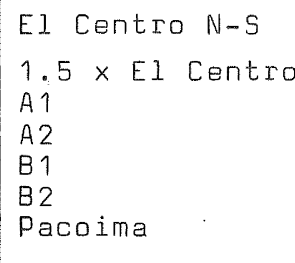 & $\begin{array}{c}1.5 \complement_{\mathrm{d}} \\
" 1 \\
" 1 \\
" 1 \\
" 1\end{array}$ & $\begin{array}{r}31 \\
64 \\
52 \\
48 \\
39 \\
32 \\
151\end{array}$ & $\begin{array}{r}9 \\
18 \\
15 \\
14 \\
11 \\
9 \\
40\end{array}$ & $\begin{array}{l}2007 \\
2587 \\
2228 \\
1980 \\
2058 \\
2011 \\
2667\end{array}$ & $\begin{array}{l}0.33 \\
0.43 \\
0.37 \\
0.33 \\
0.34 \\
0.33 \\
0.44\end{array}$ & $\begin{array}{c}0.225 \\
" 1 \\
" 1 \\
" 1 \\
" 1\end{array}$ \\
\hline 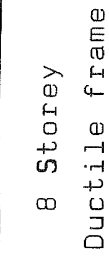 & $\begin{array}{l}\text { E1 Centro } \\
1.5 \times \text { El Centro } \\
\text { A1 } \\
\text { A2 } \\
\text { B1 } \\
\text { B2 } \\
\text { Pacoima }\end{array}$ & 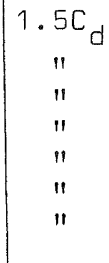 & $\begin{array}{l}151 \\
235 \\
143 \\
135 \\
124 \\
106 \\
393\end{array}$ & $\begin{array}{l}24 \\
39 \\
30 \\
28 \\
24 \\
20 \\
76\end{array}$ & $\begin{array}{r}949 \\
1122 \\
1133 \\
1079 \\
1240 \\
1088 \\
1400\end{array}$ & $\begin{array}{l}0.16 \\
0.18 \\
0.19 \\
0.18 \\
0.20 \\
0.18 \\
0.23\end{array}$ & $\begin{array}{l}0.114 \\
" 1 \\
" 1 \\
" 1 \\
" 1 \\
\text { " }\end{array}$ \\
\hline
\end{tabular}

(a) Dynamic Analysis Results

\begin{tabular}{|c|c|c|c|c|c|c|c|c|c|c|}
\hline & \multirow{2}{*}{$\begin{array}{l}\text { Earthquake } \\
\text { Record }\end{array}$} & \multicolumn{9}{|c|}{$\begin{array}{cllll}F & 1 & 0 & 0 & \mathrm{r}\end{array}$} \\
\hline & & G & 1 & 2 & 3 & 4 & 5 & 6 & 7 & 8 \\
\hline 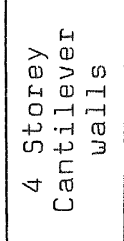 & $\begin{array}{l}\text { E1 Centro } \\
1.5 \times \text { X1 Centro } \\
\text { A1 } \\
\text { A2 } \\
\text { B1 } \\
\text { B2 } \\
\text { Pacoima }\end{array}$ & $\begin{array}{r}.35 \\
.52 \\
.33 \\
.45 \\
.37 \\
.31 \\
1.23\end{array}$ & $\begin{array}{r}.46 \\
.82 \\
.56 \\
.47 \\
.49 \\
.47 \\
1.48\end{array}$ & $\begin{array}{r}.51 \\
.73 \\
.61 \\
.45 \\
.54 \\
.52 \\
1.76\end{array}$ & $\begin{array}{r}.50 \\
.61 \\
.50 \\
.46 \\
.53 \\
.45 \\
1.20\end{array}$ & $\begin{array}{l}.64 \\
.97 \\
.75 \\
.70 \\
.69 \\
.64 \\
1.34\end{array}$ & & & & \\
\hline 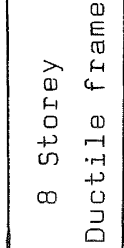 & $\begin{array}{l}\text { E1 Centro } \\
1.5 \times E 1 \text { Centro } \\
\text { A1 } \\
\text { A2 } \\
\text { B1 } \\
\text { B2 } \\
\text { Pacoima }\end{array}$ & $\begin{array}{r}.35 \\
.52 \\
.33 \\
.45 \\
.37 \\
.31 \\
1.23\end{array}$ & $\begin{array}{r}.31 \\
.50 \\
.36 \\
.33 \\
.35 \\
.33 \\
1.10\end{array}$ & $\begin{array}{r}.30 \\
.46 \\
.33 \\
.35 \\
.40 \\
.31 \\
1.03\end{array}$ & $\begin{array}{l}.34 \\
.41 \\
.36 \\
.36 \\
.40 \\
.37 \\
.80\end{array}$ & $\begin{array}{l}.34 \\
.35 \\
.34 \\
.31 \\
.34 \\
.34 \\
.81\end{array}$ & $\begin{array}{l}.36 \\
.50 \\
.36 \\
.38 \\
.34 \\
.32 \\
.75\end{array}$ & $\begin{array}{l}.30 \\
.35 \\
.34 \\
.39 \\
.35 \\
.38 \\
.63\end{array}$ & $\begin{array}{l}.33 \\
.47 \\
.35 \\
.30 \\
.35 \\
.31 \\
.67\end{array}$ & $\begin{array}{l}.42 \\
.54 \\
.37 \\
.39 \\
.45 \\
.40 \\
.81\end{array}$ \\
\hline
\end{tabular}

(b) Max. Absolute Floor Accelerations (9)

TABLE 3: EFFECT OF VARYING EARTHQUAKE RECORD 


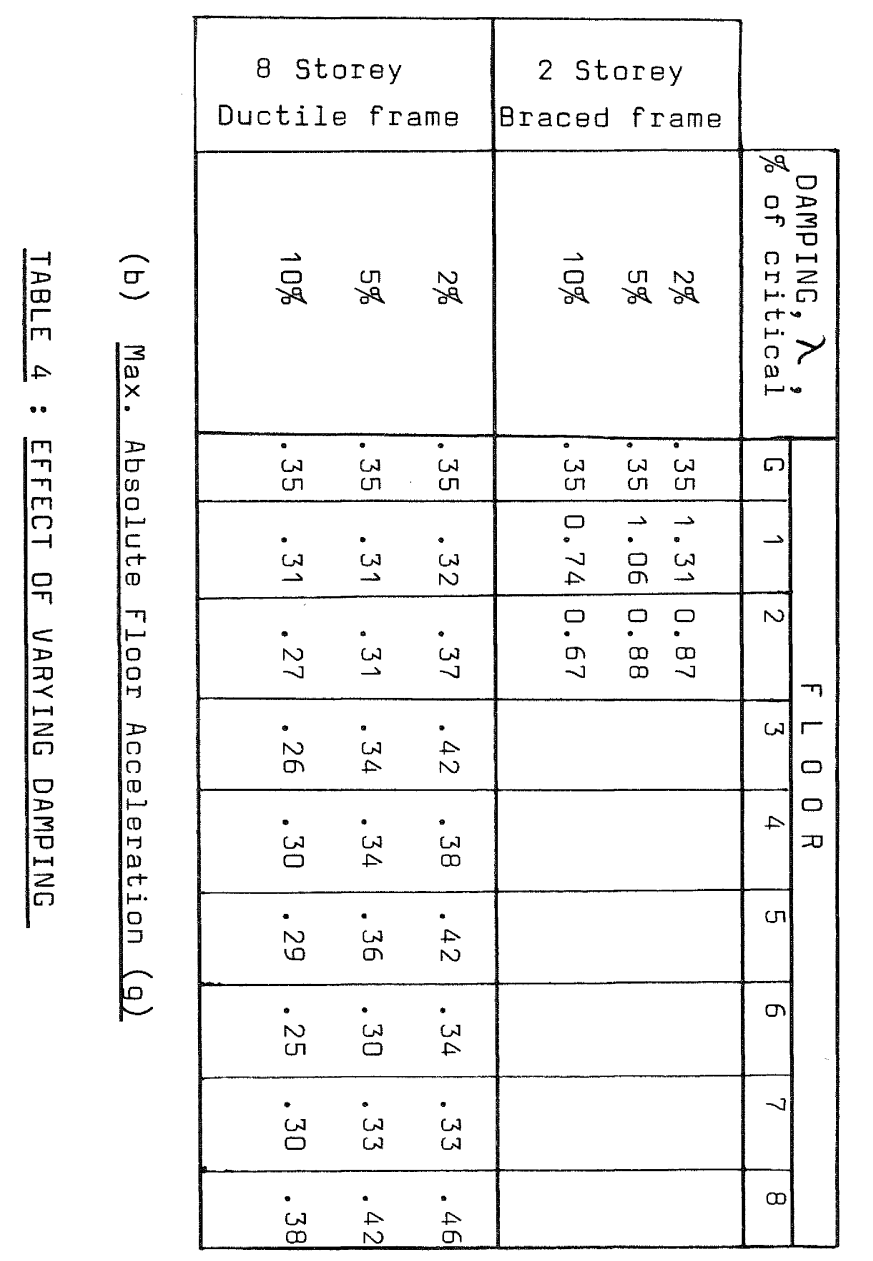

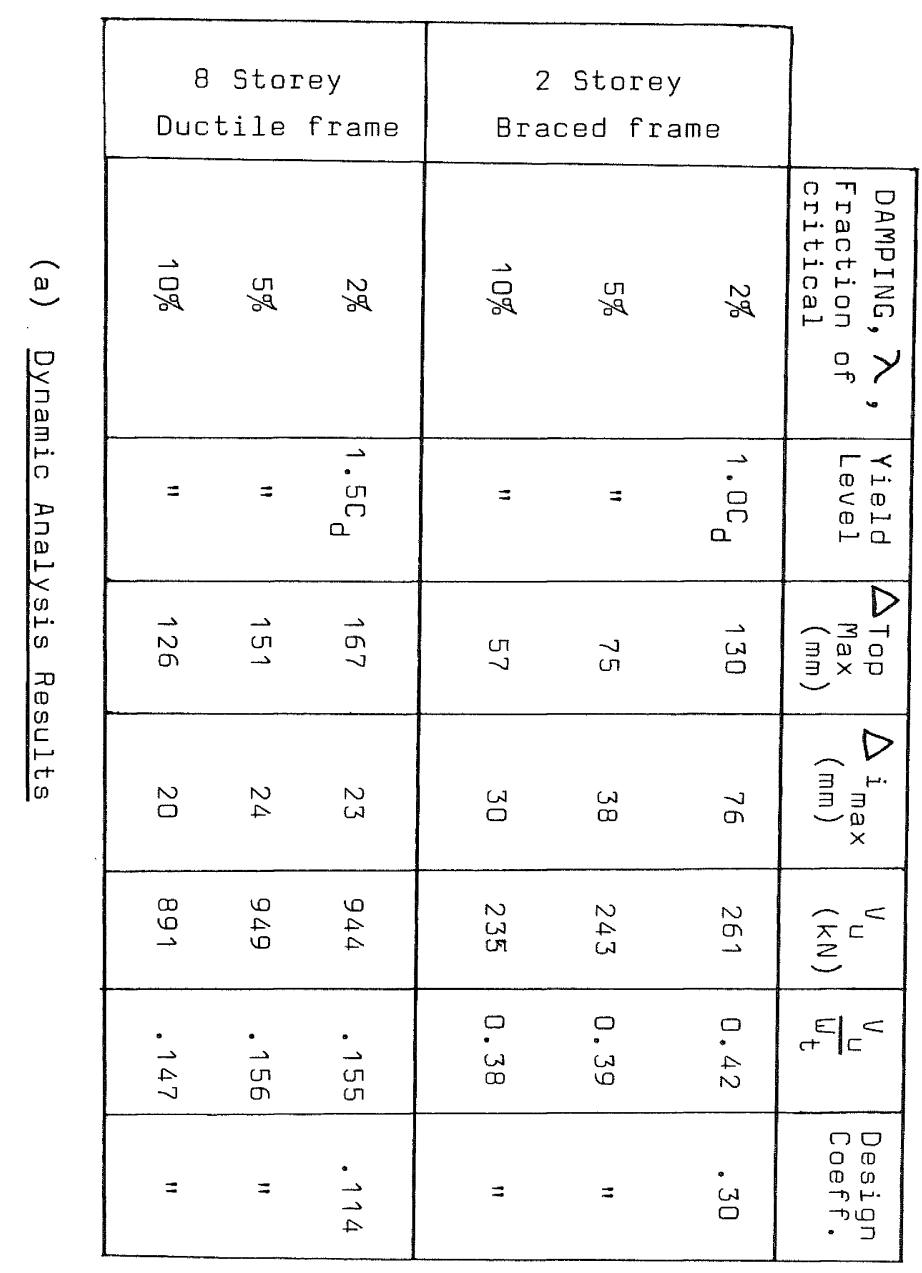

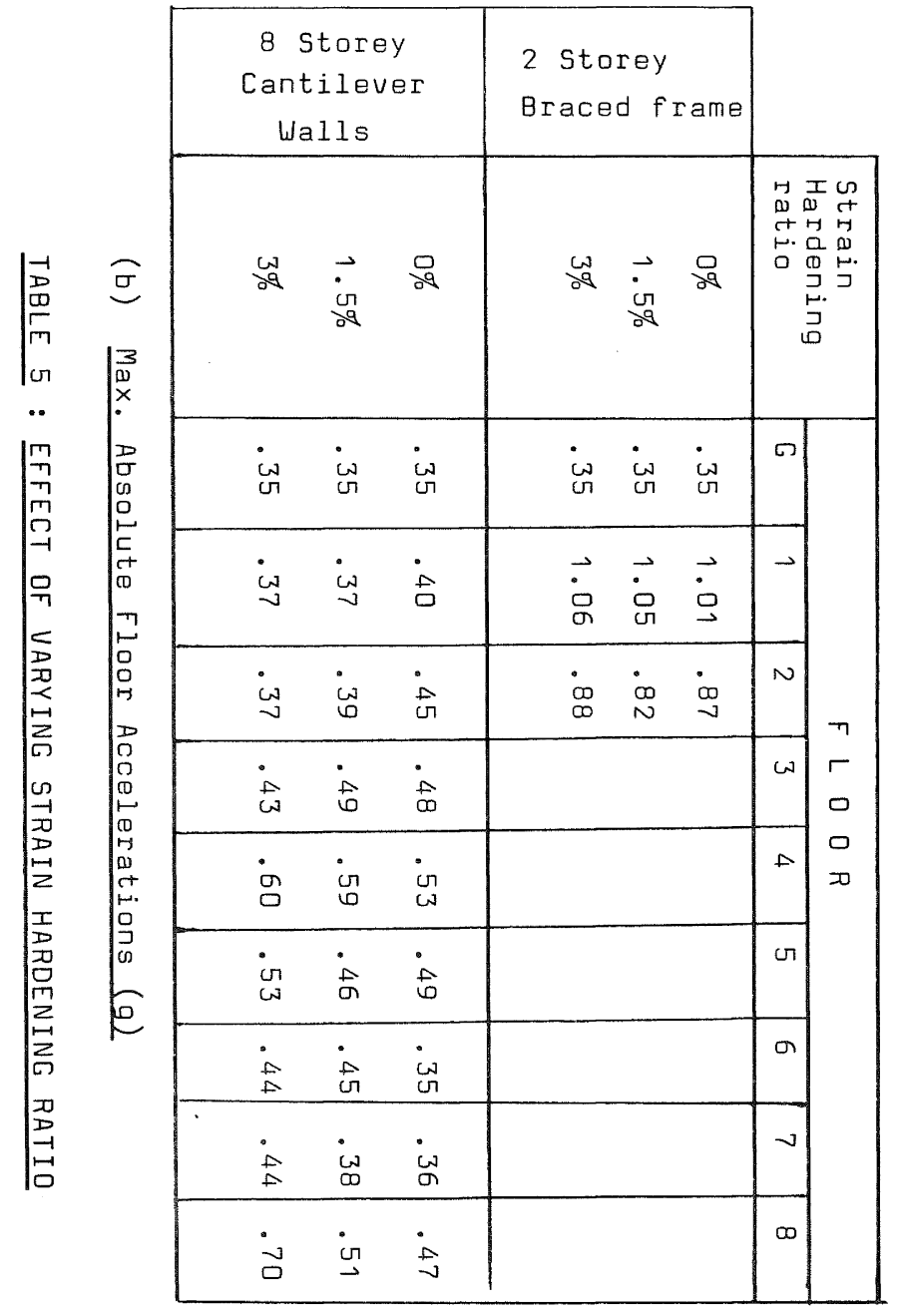

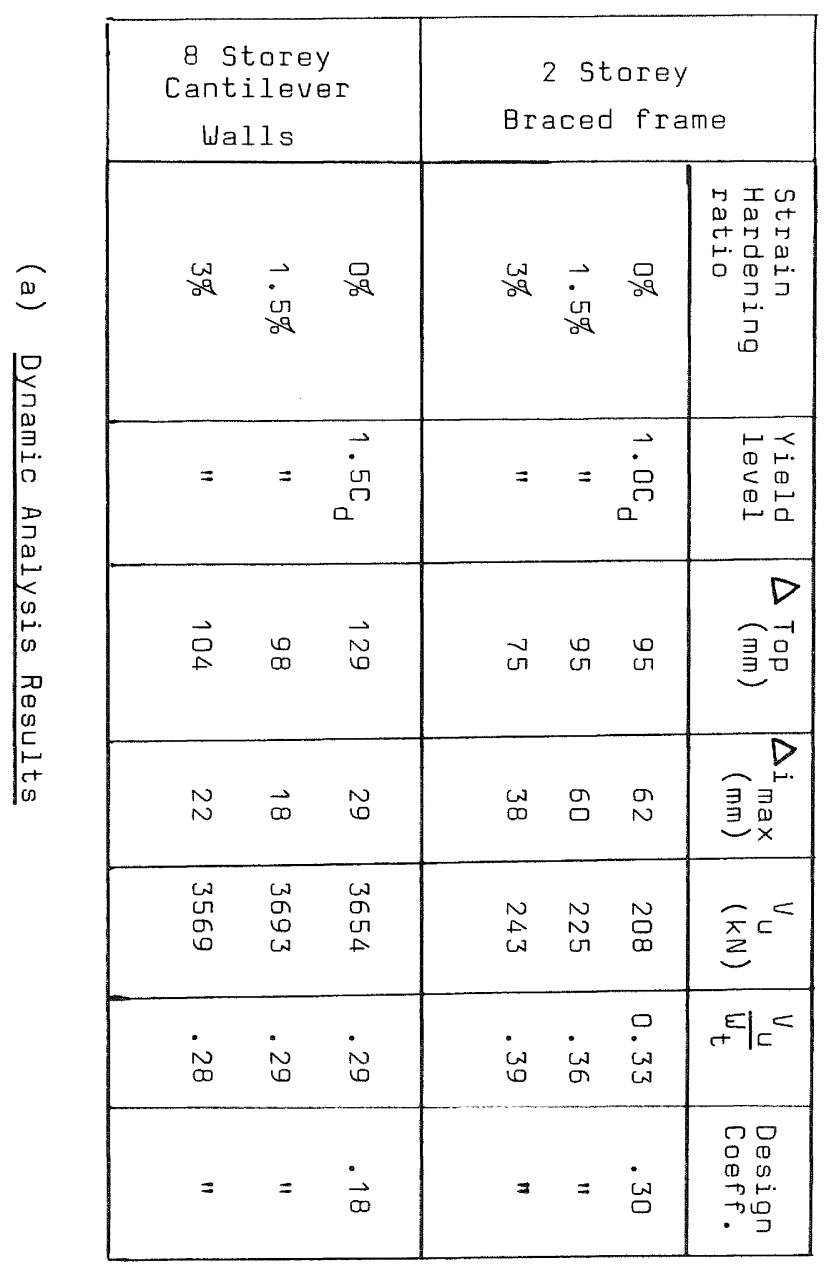


(FI) Reinforced Concrete

(F2)

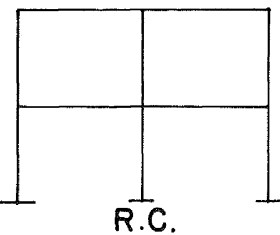

(F4)

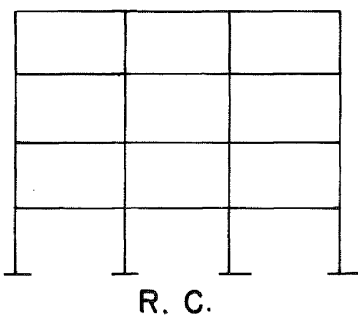

(F8)

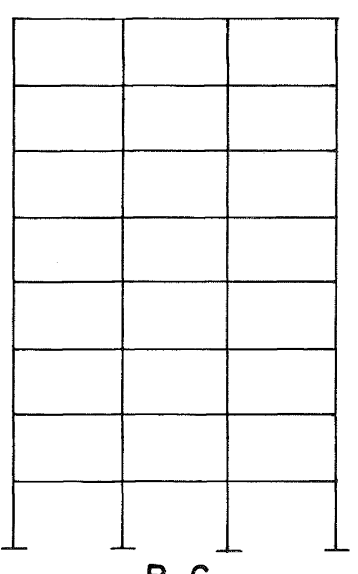

R. C.

F: Ductile Frame

W: Cantilever Shear Wall

B: Braced Frame

C: Coupled Shear Wal

(Number indicates number of storeys)
(W1)

Reinforced Masonry

(w2)

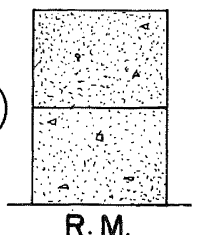

w4

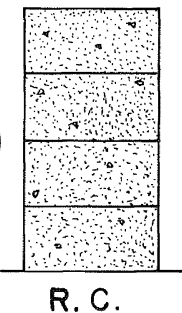

(w8)

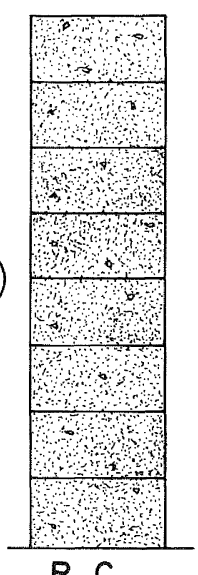

R. C.
(B1)

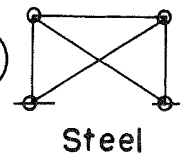

(B2)

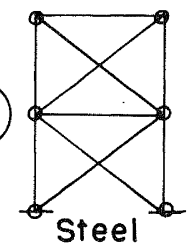

(c4)

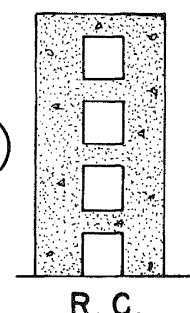

R. C

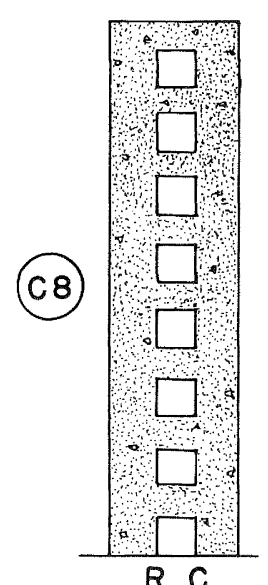

R. C.
H

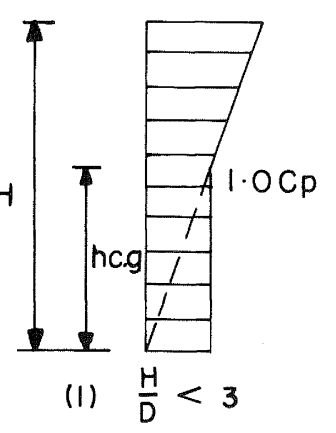

(a) NZS 4203

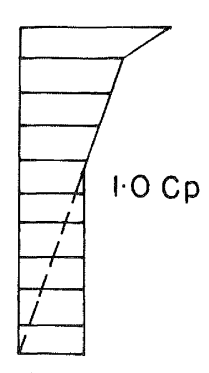

(2) $\frac{H}{D}>3$

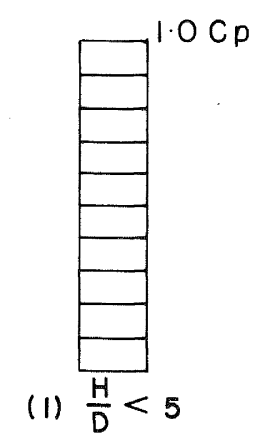

(b) SEAOC

(2) $\frac{H}{D}>5$

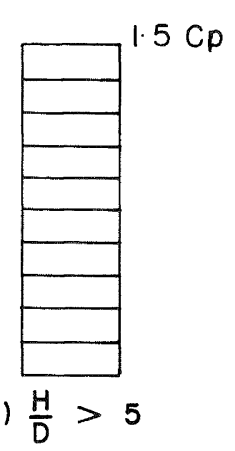

FIGURE 1: STRUCTURES ANALYSED

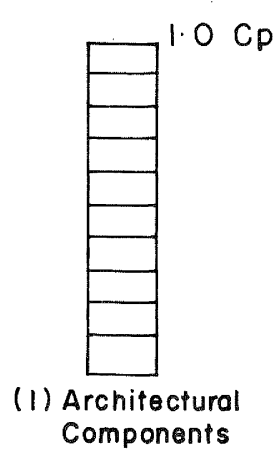

(c) ATC -3

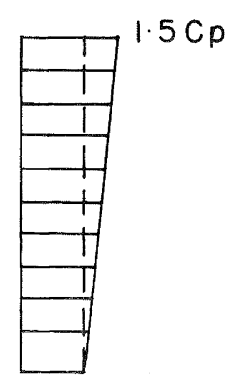

(2) Mechanical 8 Electrical Components

FIGURE 2: VARIATION OF FORCE COEFFICIENT, CP, WITH HEIGHT. 

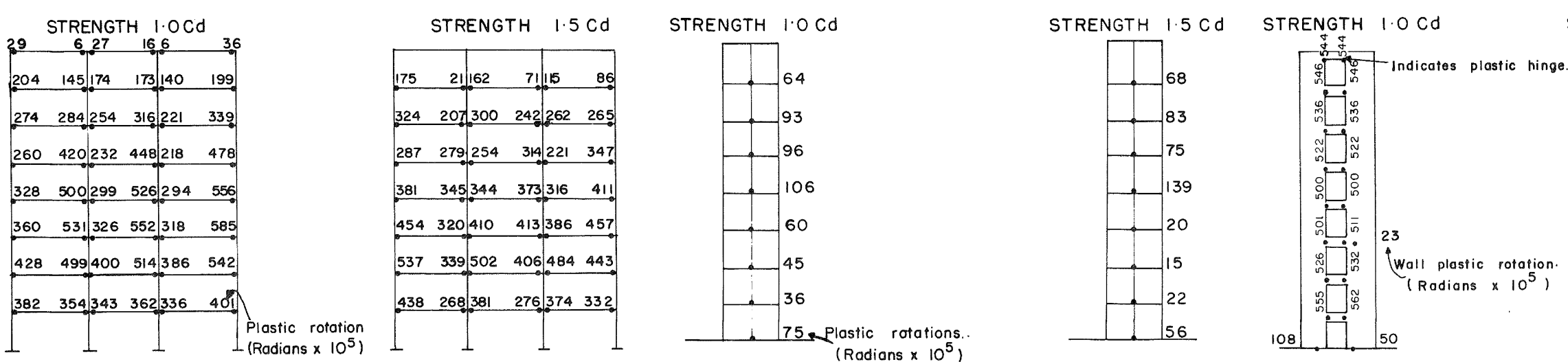

STRENGTH $1.5 \mathrm{Cd}$
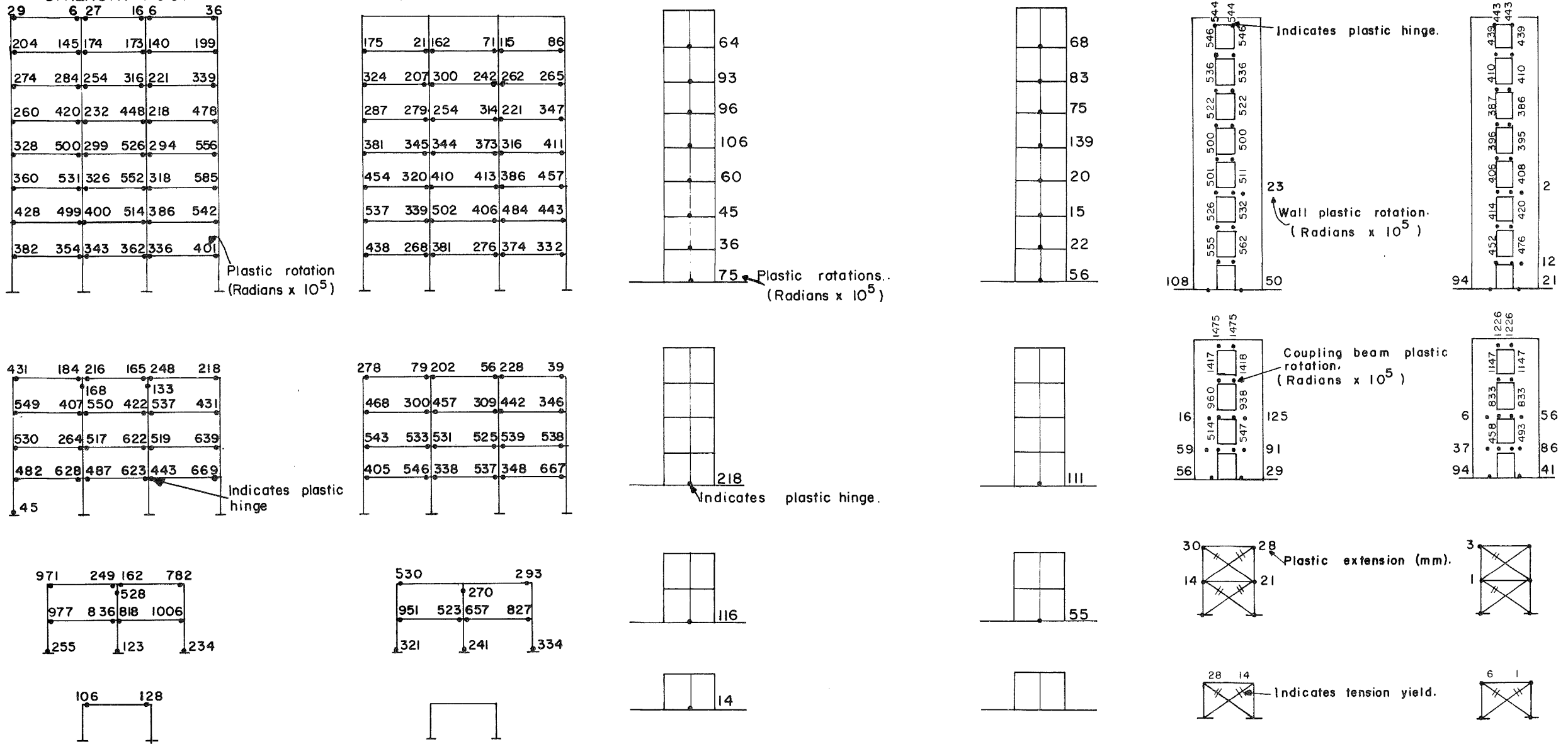

$28 \quad 14$

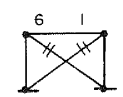

FIGURE 3: DUCTILE FRAMES: EXTENT

FIGURE 4: CANTILEVER WALLS: EXTENT AND DISTRIBUTION OF INELASTICITY

FIGURE 5: COUPLED WALLS AND BRACED FRAMES: EXTENT AND DISTRIBUTION OF INELASTICITY 


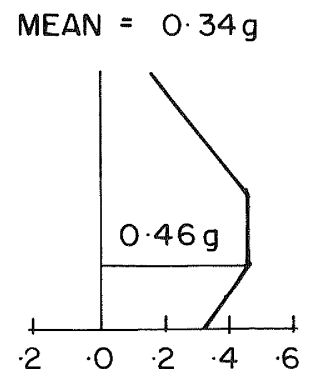

$T=2 \cdot 09 \operatorname{secs}$
$0.46 \mathrm{~g}$

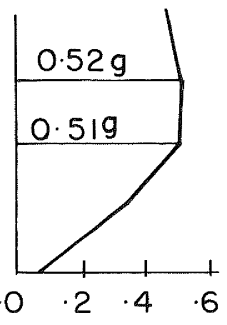

$T=2 \cdot 17 \operatorname{secs}$

Iäl max (g)

(a) 4 STOREY CANTILEVER WALL $1.5 \mathrm{Cd}$ $(V u / W+=0.24)$

MEAN $=0.150$

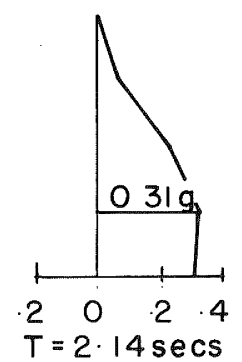

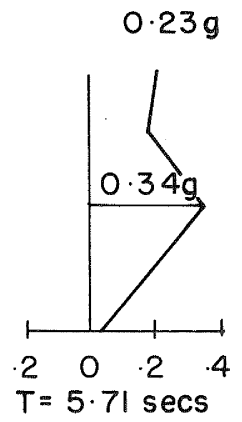

$0.23 \mathrm{~g}$

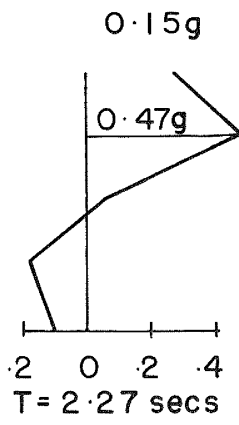

äl max $(g)$

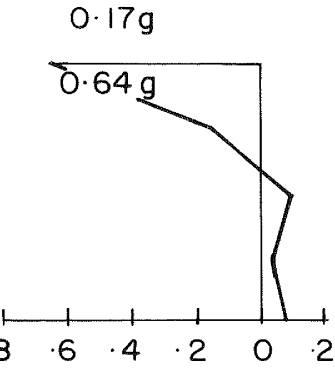

$T=2 \cdot 35$ secs

Cd

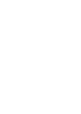


ABSOLUTE FLOOR RCCELERATIONS YIELO LEVEL: 1.5 CO DUCTILE FRaME EARTHQUAKE RECORO : EL CENTRO $1940 \mathrm{~N}$-9

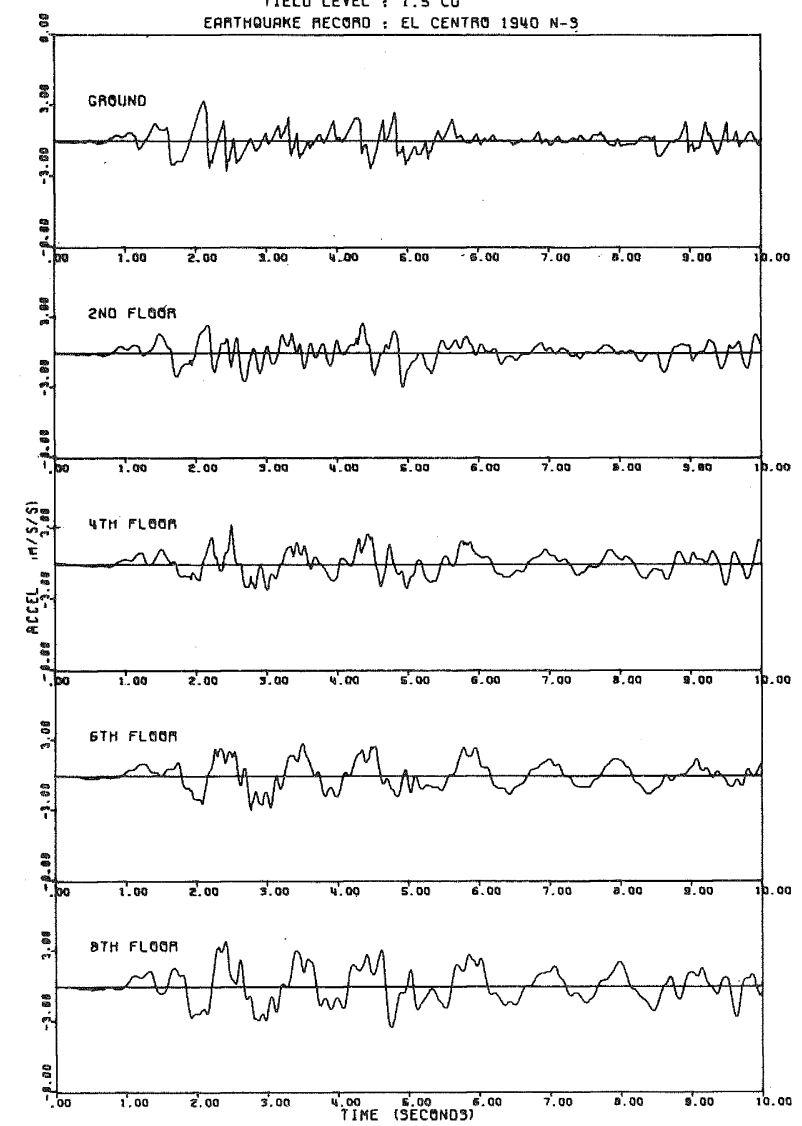

FIGURE 7: FLOOR ACCELERATIONS: 8 STOREY DUCTILE FRAME, $1.5 \mathrm{Cd}$
ABSOLUTE FLOOR ACCELERRTIONS

STRUCTURE: ERTOAEY DUCTILE FRAM
I ELLO LEVEL F EQSTIC

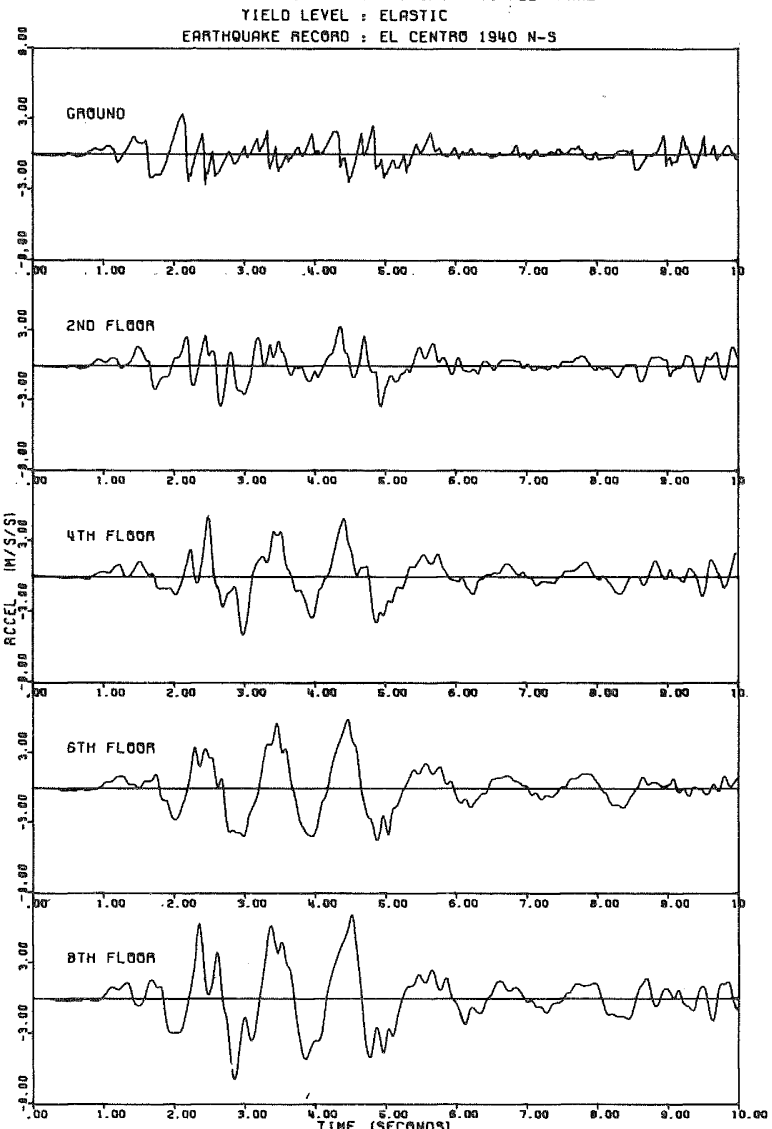

FIGURE 8: FLOOR ACCELERATIONS: 8 STOREY DUCTILE FRAMÉ,ELASTIC
RBSOLUTE FLOOR ACCELERATIONS STILEVER HALL

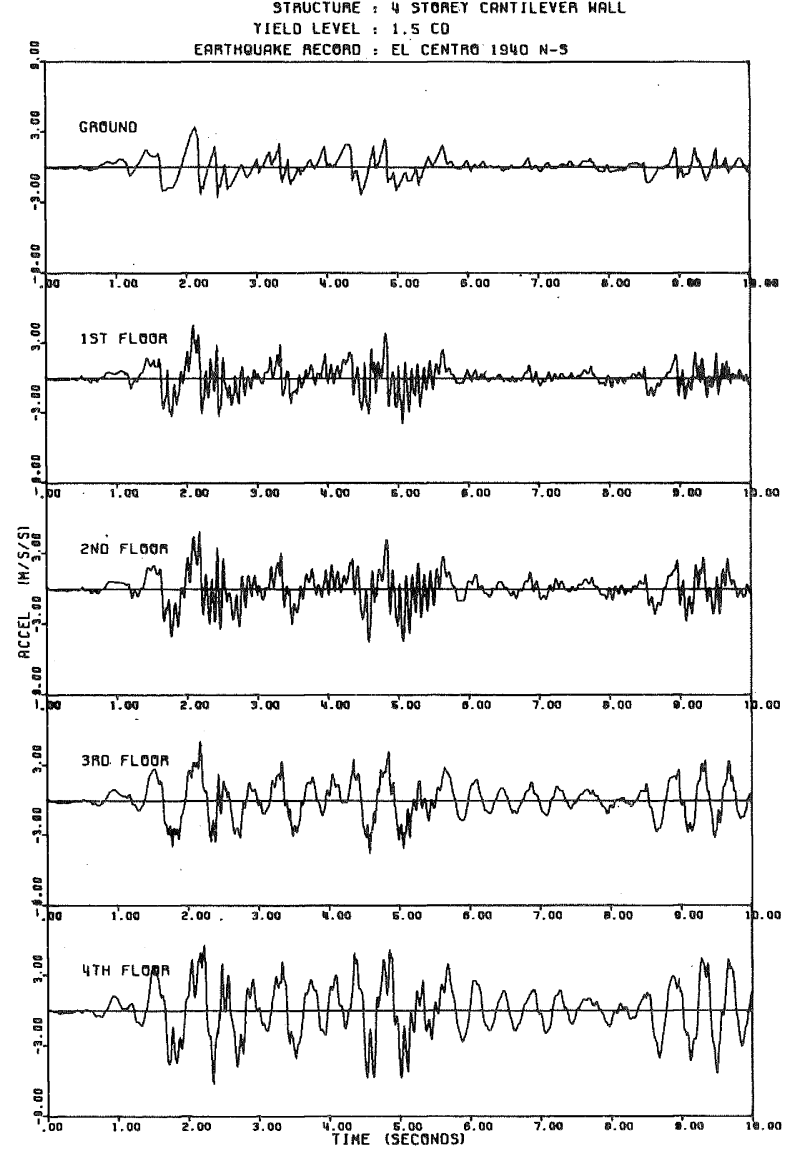

FIGURE 9: FLOOR ACCELERATIONS: 4 STOREY CANTILEVER WALL, $1.5 \mathrm{Cd}$ 

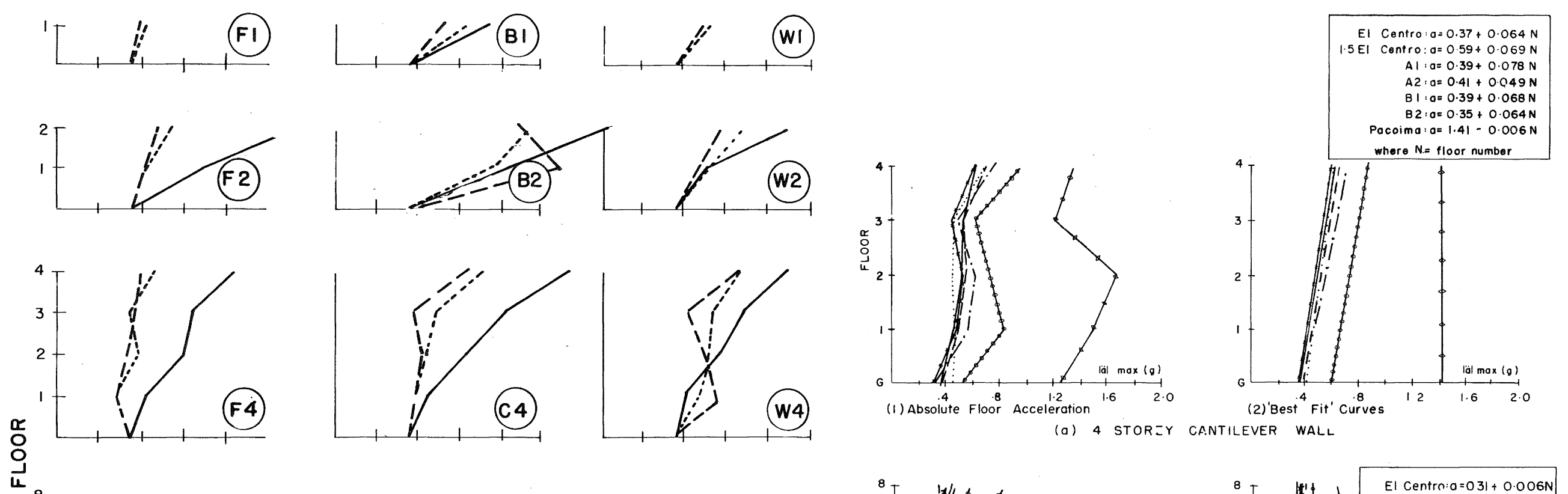

$\stackrel{N}{O}$ (a) 4 STOREY CANTILEVER WALL
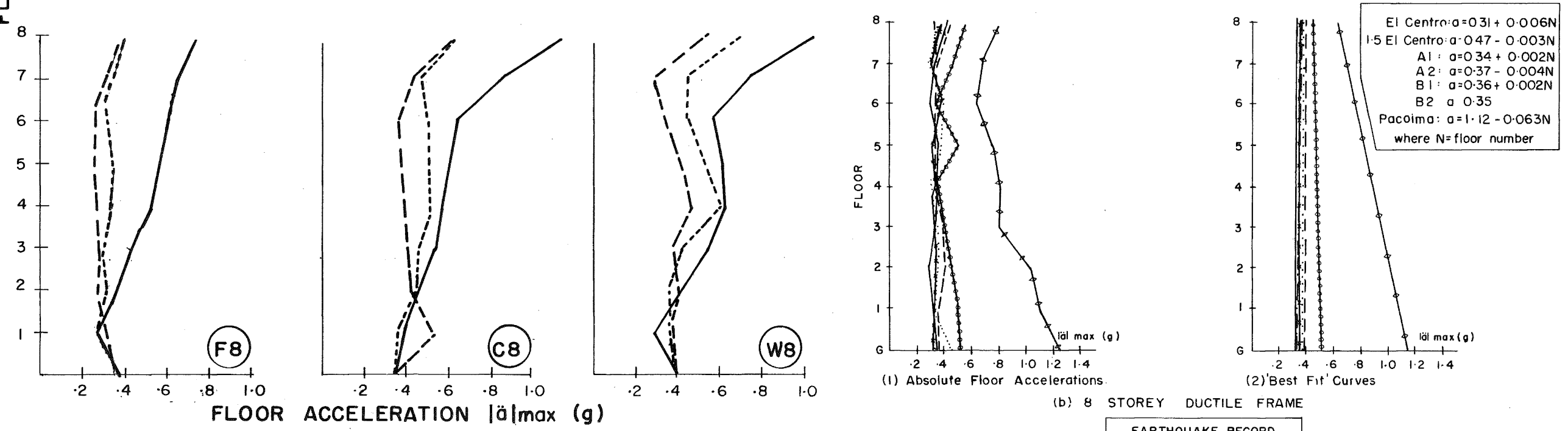

(b) 8 STOREY DUCTILE FRAME

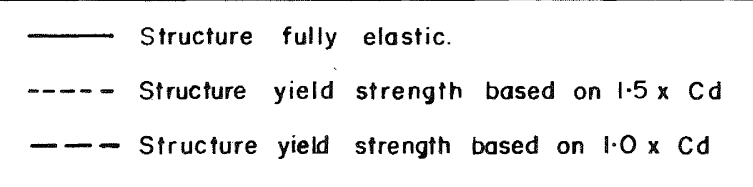

FIGURE 10: ABSOLUTE MAXIMUM FLOOR ACCELERATIONS

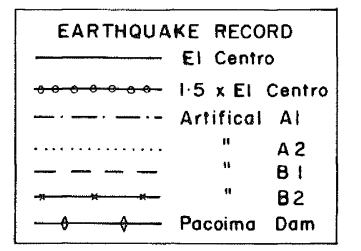

FIGURE 11: ABSOLUTE MAXIMUM FLOOR ACCELERATIONS: EFFECT OF VARYING EARTHQUAKE RECORD 

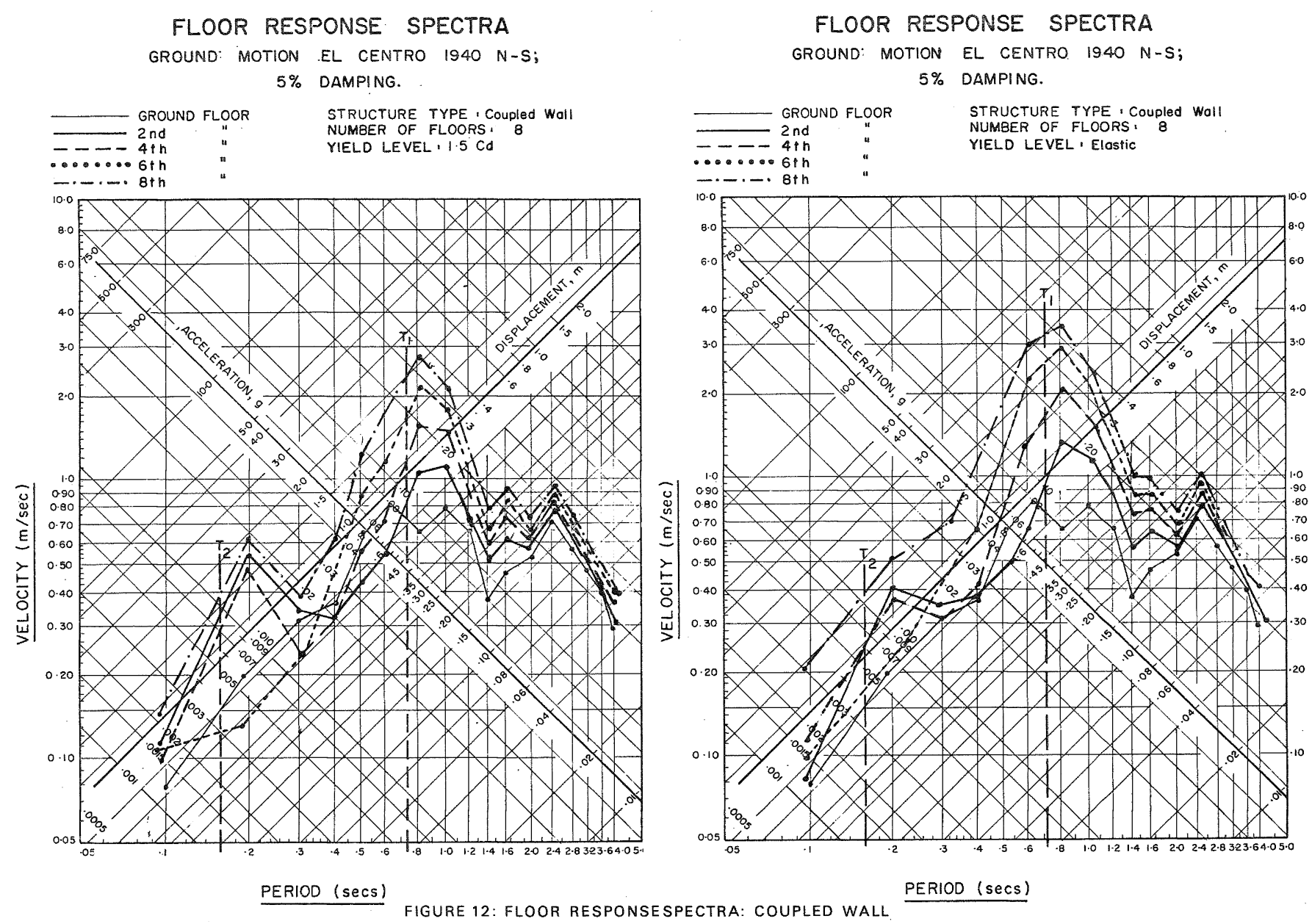
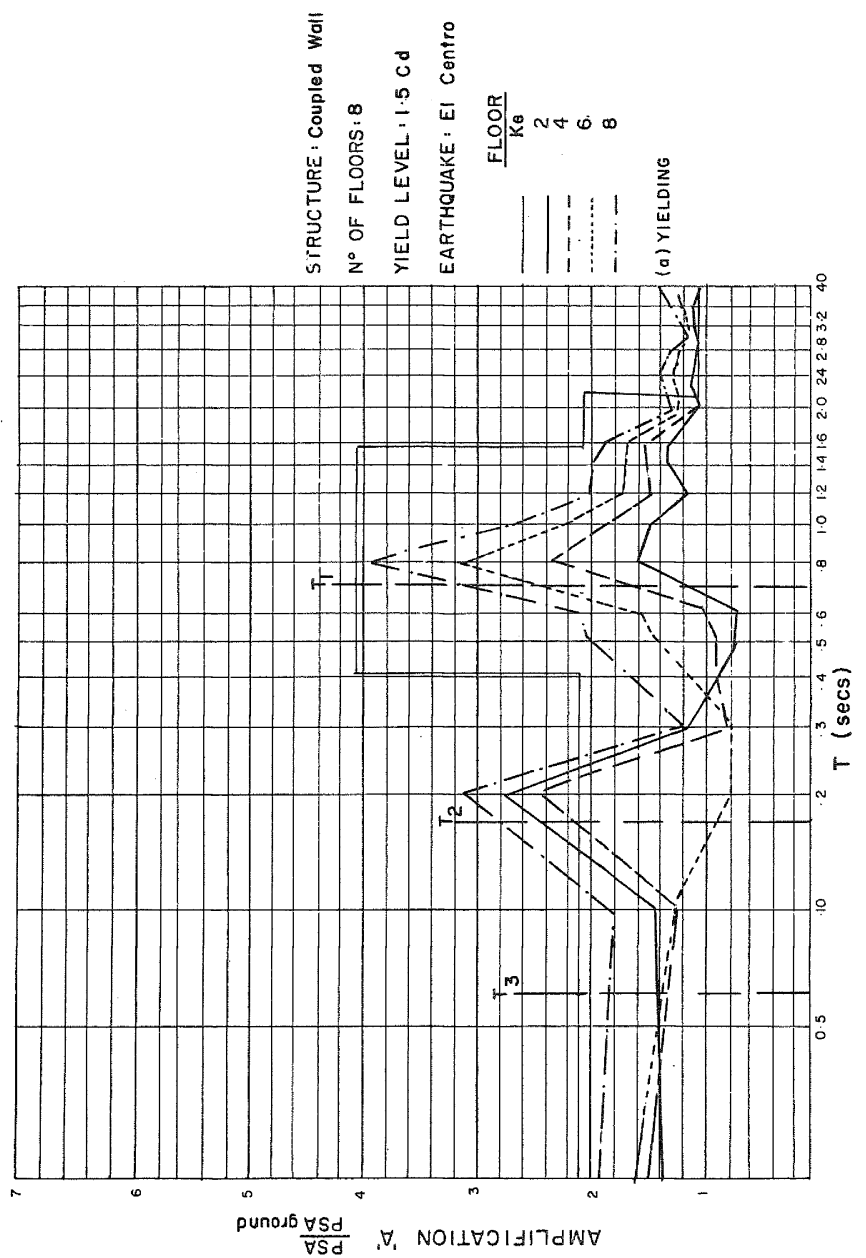
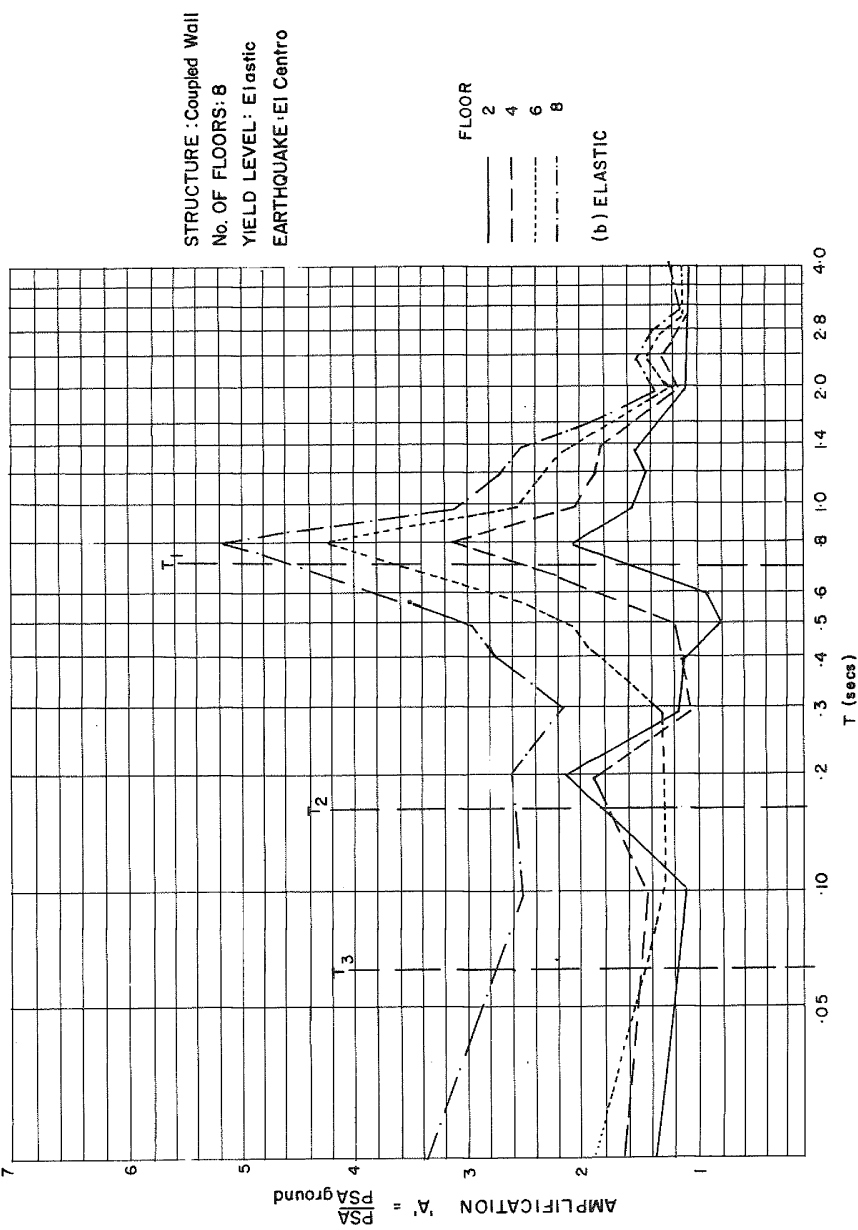

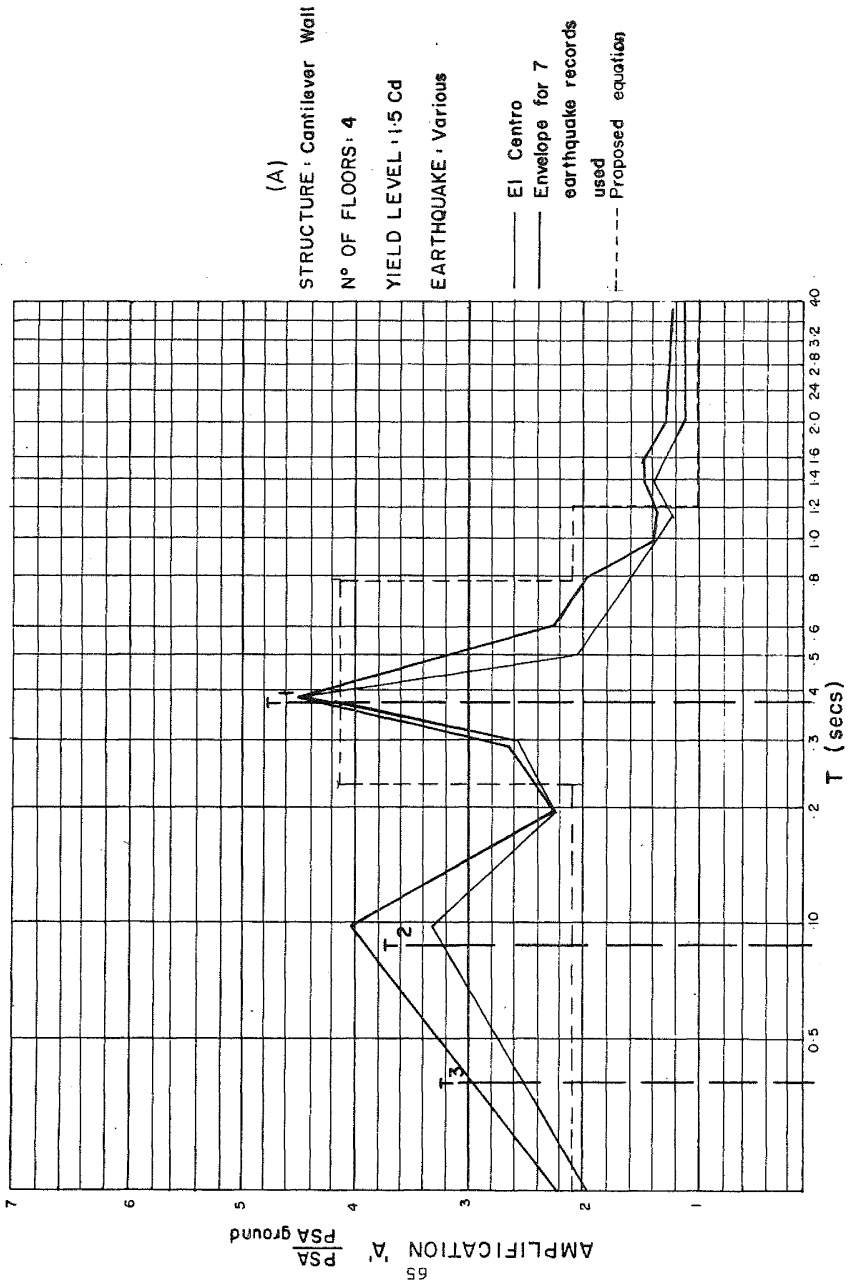

FIGURE 14: EFFECT OF VARYING EARTHQUAKE RECORD

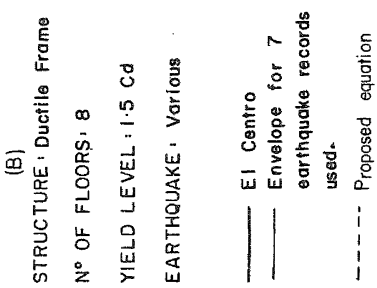

这哭安

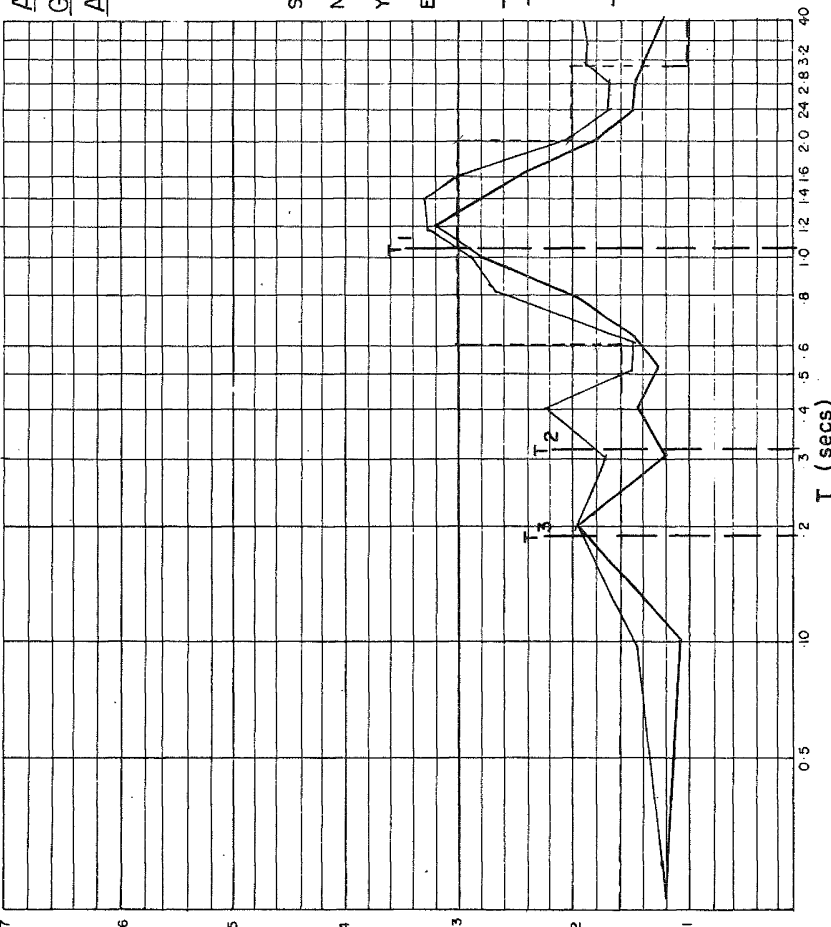

punod $\frac{\forall S d}{\nabla S d}, \forall$, NOILVJIJI)
FLOOR RESPONSE SPECTRA

EL CENTRO $5 \%$ DAMPING

UPPER BOUND FOR ALL FLOORS OF ALL STRUCTURES
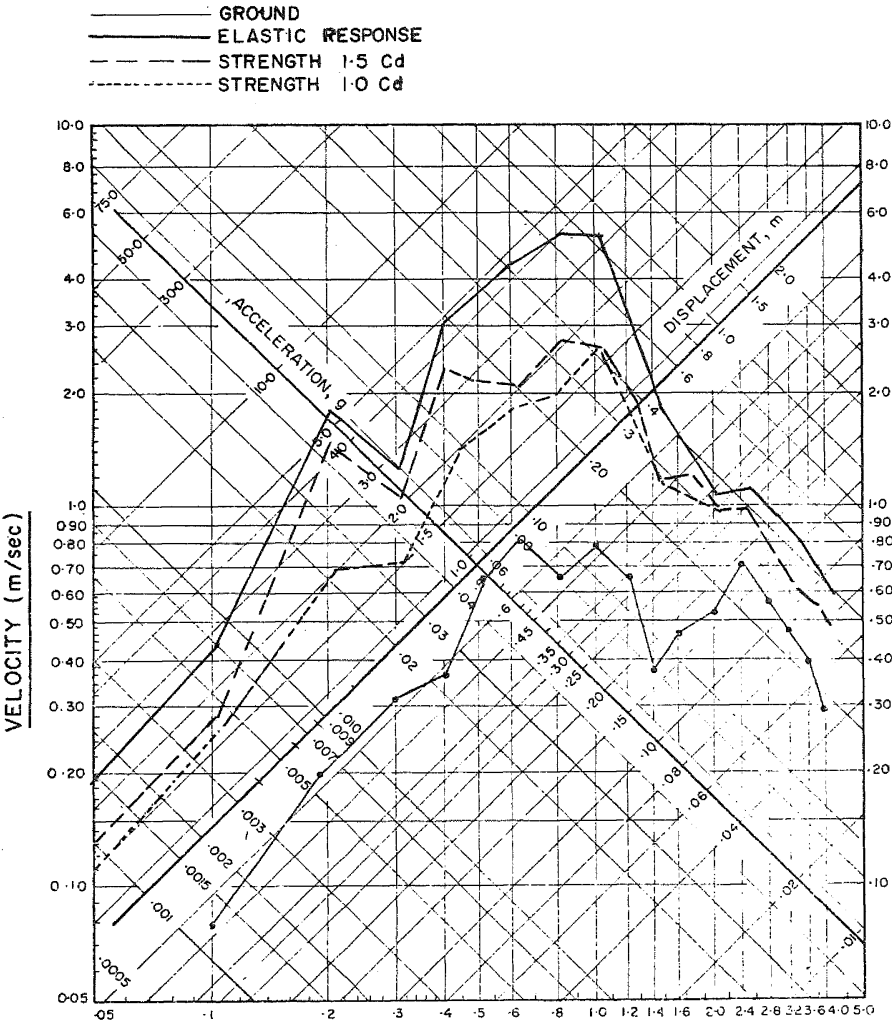

FLOOR RESPONSE SPECTRA

EL CENTRO 1940 5\% DAMPING

ACCELERATIONS FOR ALL STRUCTURES, ALL FLOORS SMOOTHED ENVELOPE

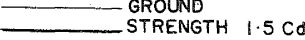

- - - REFERENCE 12 (Elostic)

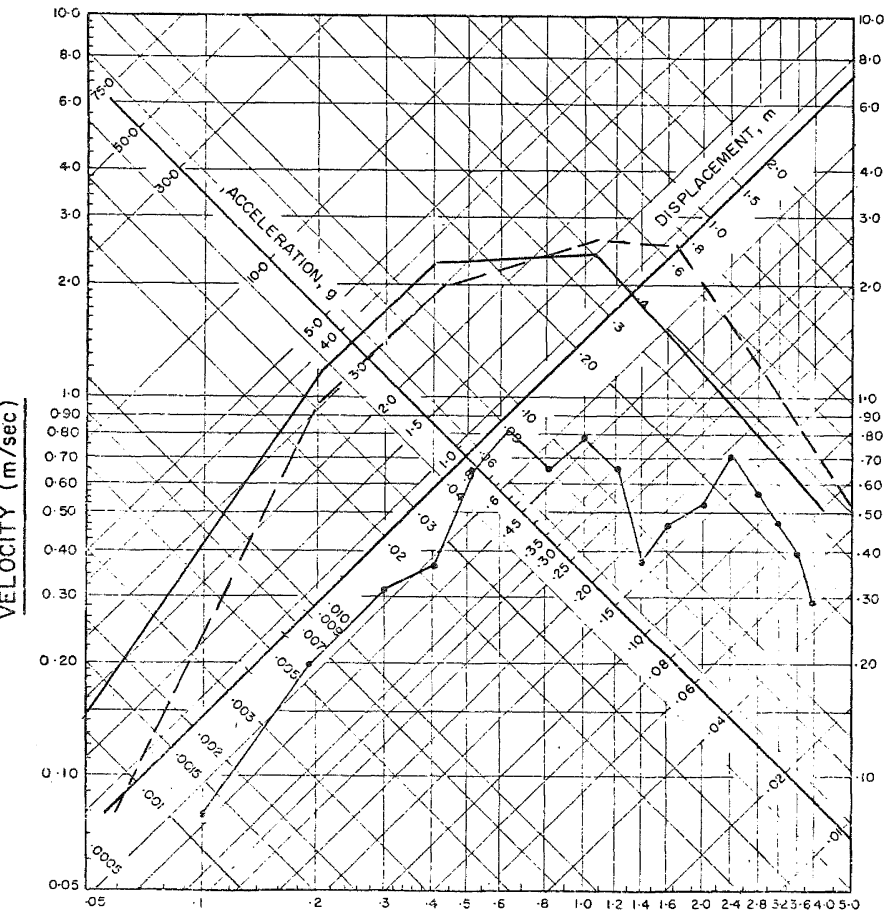

